\title{
Development of mandibular, hyoid and hypobranchial muscles in the zebrafish: homologies and evolution of these muscles within bony fishes and tetrapods Rui Diogo*1,2, Yaniv Hinits ${ }^{1}$ and Simon M Hughes ${ }^{1}$
}

Address: ${ }^{1}$ MRC Centre for Developmental Neurobiology and Randall Division for Cell and Molecular Biophysics, New Hunt's House, King's College London SE1 1UL, UK and 2Department of Anthropology, George Washington University, USA

Email: Rui Diogo* - ruidiogo@gwu.edu; Yaniv Hinits - yaniv.hinits@kcl.ac.uk; Simon M Hughes - simon.hughes@kcl.ac.uk

* Corresponding author

Published: 28 February 2008

BMC Developmental Biology 2008, 8:24 doi:10.1/86/|47|-2/3X-8-24

This article is available from: http://www.biomedcentral.com/I47I-2I3X/8/24

(C) 2008 Diogo et al; licensee BioMed Central Ltd.

This is an Open Access article distributed under the terms of the Creative Commons Attribution License (http://creativecommons.org/licenses/by/2.0), which permits unrestricted use, distribution, and reproduction in any medium, provided the original work is properly cited.
Received: 15 April 2007

Accepted: 28 February 2008

\begin{abstract}
Background: During vertebrate head evolution, muscle changes accompanied radical modification of the skeleton. Recent studies have suggested that muscles and their innervation evolve less rapidly than cartilage. The freshwater teleostean zebrafish (Danio rerio) is the most studied actinopterygian model organism, and is sometimes taken to represent osteichthyans as a whole, which include bony fishes and tetrapods. Most work concerning zebrafish cranial muscles has focused on larval stages. We set out to describe the later development of zebrafish head muscles and compare muscle homologies across the Osteichthyes.
\end{abstract}

Results: We describe one new muscle and show that the number of mandibular, hyoid and hypobranchial muscles found in four day-old zebrafish larvae is similar to that found in the adult. However, the overall configuration and/or the number of divisions of these muscles change during development. For example, the undivided adductor mandibulae of early larvae gives rise to the adductor mandibulae sections A0, AI-OST, A2 and A $\omega$, and the protractor hyoideus becomes divided into dorsal and ventral portions in adults. There is not always a correspondence between the ontogeny of these muscles in the zebrafish and their evolution within the Osteichthyes. All of the 13 mandibular, hyoid and hypobranchial muscles present in the adult zebrafish are found in at least some other living teleosts, and all except the protractor hyoideus are found in at least some extant non-teleost actinopterygians. Of these muscles, about a quarter (intermandibularis anterior, adductor mandibulae, sternohyoideus) are found in at least some living tetrapods, and a further quarter (levator arcus palatini, adductor arcus palatini, adductor operculi) in at least some extant sarcopterygian fish.

Conclusion: Although the zebrafish occupies a rather derived phylogenetic position within actinopterygians and even within teleosts, with respect to the mandibular, hyoid and hypobranchial muscles it seems justified to consider it an appropriate representative of these two groups. Among these muscles, the three with clear homologues in tetrapods and the further three identified in sarcopterygian fish are particularly appropriate for comparisons of results between the actinopterygian zebrafish and the sarcopterygians. 


\section{Background}

The Osteichthyes, including bony fishes and tetrapods, is a highly speciose group of gnathostomes, comprising more than 42,000 living species. Two main osteichthyan groups are usually recognized: the Actinopterygii (rayfins, $>28,000$ extant species) and Sarcopterygii (lobefins and tetrapods, $>24,000$ living species; note that bony fishes constitute a paraphyletic group, as they only become monophyletic if tetrapods are excluded; Fig. 1) [1]. One of the most studied osteichthyan model organisms is the zebrafish Danio rerio, a small actinopterygian freshwater fish from the teleostean order Cypriniformes (Fig. 1) [25]. Comparisons between zebrafish and other vertebrates are often made in developmental studies, the zebrafish being sometimes taken as a 'good representative' of teleosts, of actinopterygians and even of bony fishes [2]. To what extent is this true for the cranial musculature?
Among studies dealing with zebrafish myology, only a few focus on cranial muscles, and these mainly concern larval stages (e.g. [3,5-10]). In fact, as stated by Schilling, "no study has carefully described the anatomy of the musculature of the adult zebrafish" [5]. This is surprising given that the cranial myology of other adult members of the order Cypriniformes has been described in detail in the literature [11-20]. Schilling provided a short summary of the myology of the adult zebrafish but, as he recognized, this was mainly based on an extrapolation from his "own observations of larval cranial muscles" and from "studies in other teleosts", and not from direct dissection of adult specimens of Danio rerio [5].

Aside from the poor knowledge of the late stages of development of zebrafish cranial muscles there are also problems with the identification of homologies between some of these muscles and those of other vertebrates. The main reason for the scarce knowledge of the homologies and

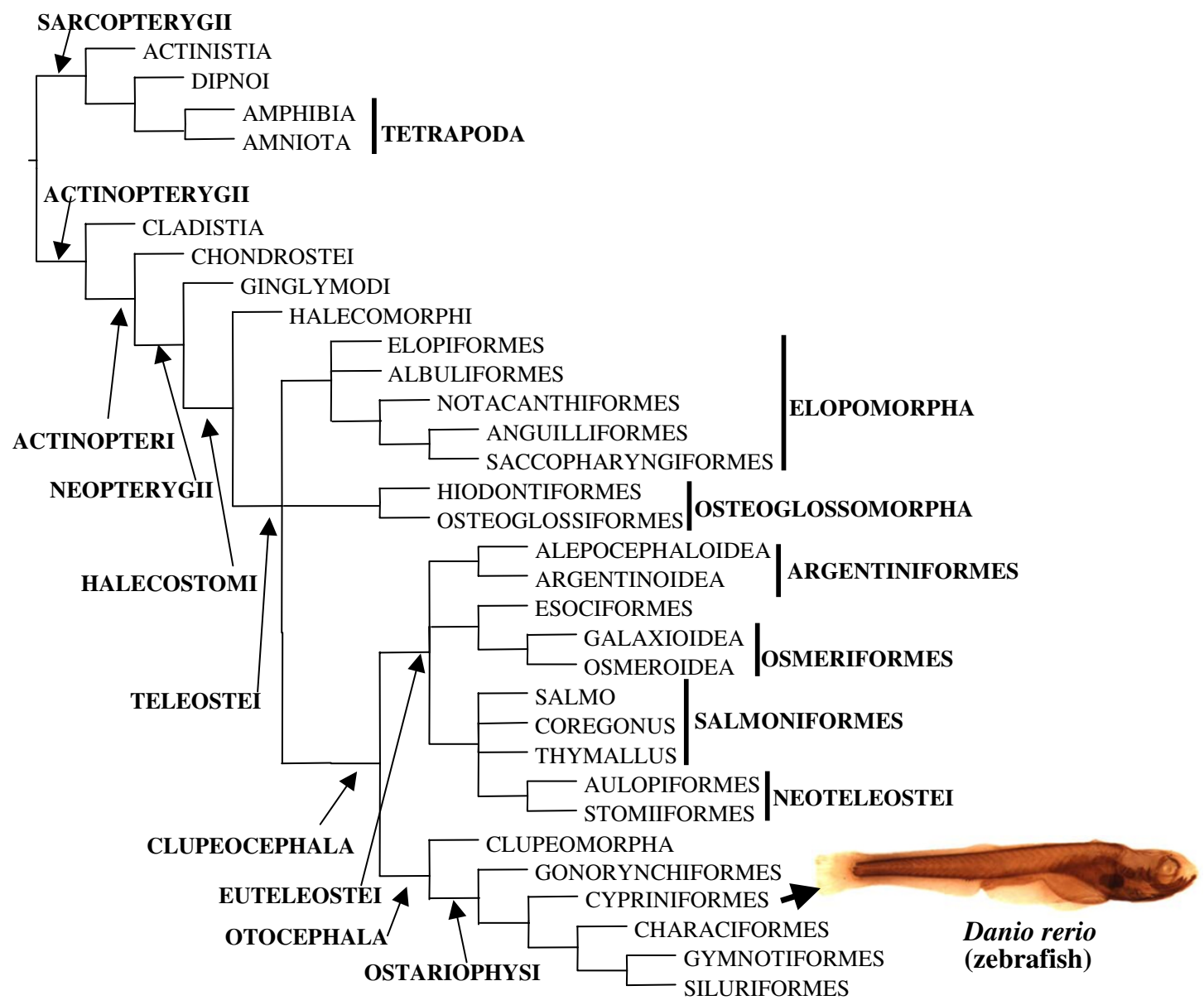

Figure I

Phylogenetic relationships among the major extant osteichthyan groups (modified from Diogo [36]: the Elopomorpha, Osteoglossomorpha and Clupeocephala are placed in a trichotomy; see also [78]). 
evolution of osteichthyan cranial muscles is that most of the works dealing with the comparative anatomy of Osteichthyes concern skeletal structures. The most detailed published comparative analyses of osteichthyan cranial muscles based on direct observation of a wide range of taxa derive from long ago [12,21-23]. Edgeworth's volume [12] continues to be a fundamental source of information on vertebrate muscles. However, Edgeworth could not, for instance, study the muscles of the then undiscovered coelacanth Latimeria chalumnae [24], or know of the essential role of neural crest cells in the development and patterning of vertebrate cranial muscles [3,25-33].

About 15 years ago, Miyake et al. [34] published an analysis of the cranial muscles of chondrichthyan batoids, in which they re-examined and discussed various hypotheses proposed by Edgeworth [12]. They noted that "Noden [26-28] elegantly demonstrated with quail-chick chimeras that (certain) cranial muscles are embryologically of somitic origin and not, as commonly thought, of lateral plate origin, and in doing so corroborated the nearly forgotten work of Edgeworth". They also pointed out that molecular developmental studies such as Hatta et al. $[7,35]$ "have corroborated one of Edgeworth's findings: the existence of one premyogenic condensation (the constrictor dorsalis) in the cranial region of teleost fish". Edgeworth [12] recognized various presumptive premyogenic condensations: mandibular, hyoid, branchial, epibranchial, and hypobranchial. According to him, developmental pathways leading from these condensations to myogenesis in each cranial arch involve migration of premyogenic cells, differentiation of myofibers, directional growth of myofibers and possibly interactions with surrounding structures. These events occur in very specific locations, e.g. dorsal, medial or ventral areas of each arch. Although exceptions may occur [36], Edgeworth's mandibular muscles are generally innervated by the Vth nerve, the hyoid muscles by the VIIth nerve, and the branchial muscles by the IXth and Xth nerves. His epibranchial and hypobranchial muscles are "developed from the anterior myotomes of the body" and thus "are intrusive elements of the head"; they "retain a spinal innervation" and "do not receive any branches from the Vth, VIIth, IXth and Xth nerves". It should, however, be noted that recent developmental data has shown that head mesoderm is initially unsegmented and that, contrary to Edgeworth's hypothesis, it may not generate a migratory population of myoblasts as is the case in the anterior somites which give rise to the hypobranchial muscles. Instead, the mandibular, hyoid and branchial muscles appear to develop in situ under the influence of cephalic neural crest cells [30-33].

The main aim of the present paper is to provide a solid basis for future molecular, evolutionary and developmen- tal work concerning zebrafish cranial musculature, by addressing four main questions: 1 ) How do the mandibular, hyoid and hypobranchial muscles of zebrafish develop until they reach their adult form? 2) To which muscles of other osteichthyans do these muscles correspond? 3) Is there a correspondence between the ontogeny of these muscles in the zebrafish and their evolutionary history within the Osteichthyes? 4) Regarding these cranial muscles, is it appropriate to consider the zebrafish as a "good representative" of teleosts, of actinopterygians and/or of bony fishes?

\section{Results}

We examined the mandibular, hyoid and hypobranchial muscles of Edgeworth [12], i.e. the 'superficial cranial muscles' of Diogo and Vandewalle [37]. With exception to those few cases in which it is stated otherwise, our observations of these muscles in the early larvae analyzed mostly agree with those done in previous works $[3,5,8$ 10]. The larval branchial and ocular muscles of the zebrafish have been described [3,5-10]. The configuration of the ocular muscles in adults is essentially similar to that found in larvae (data not shown).

\section{Mandibular musculature}

According to Schilling and Kimmel, five bilateral mandibular muscles innervated by the Vth nerve are formed in the first three days of zebrafish development: the intermandibularis anterior, the intermandibularis posterior, the adductor mandibulae, the levator arcus palatini and the dilatator operculi [3]. In their study, the adductor mandibulae began myosin protein expression at 53 hours post fertilization ( $53 \mathrm{hpf}$ ), the other four mandibular muscles appearing at $62 \mathrm{hpf}$ [3]. These five muscles were found in the 4 day old (4-d) larvae examined in the present work (Fig. 2).

During development, the intermandibularis posterior becomes deeply associated with the hyoid muscle interhyoideus, forming the protractor hyoideus (Figs. 2A, B, 3, 4 and $5 \mathrm{C}$ ). In contrast to earlier stages (Figs. 2A, B and 3A), in 35-d juveniles and adults two protractor hyoideus portions, dorsal and ventral, can be recognized (Figs. 4A, B and $5 \mathrm{C}$ ). In adults, the ventral portion connects the anterior ceratohyal and ventral hypohyal bones to the ventromesial surface of the dentary bone of the mandible. The dorsal portion runs from the anterior ceratohyal to the ventromesial margin of the dentary bone (Table 1). Thus, the protractor hyoideus is a complex muscle innervated by both the Vth and VIIth nerves that results from a fusion of the posterior portion of the intermandibularis posterior to the anterior portion of the interhyoideus, followed by a longitudinal splitting to generate dorsal and ventral portions. This muscle is usually, but not always, associated with the elevation (protraction) of the hyoid bars, as well 

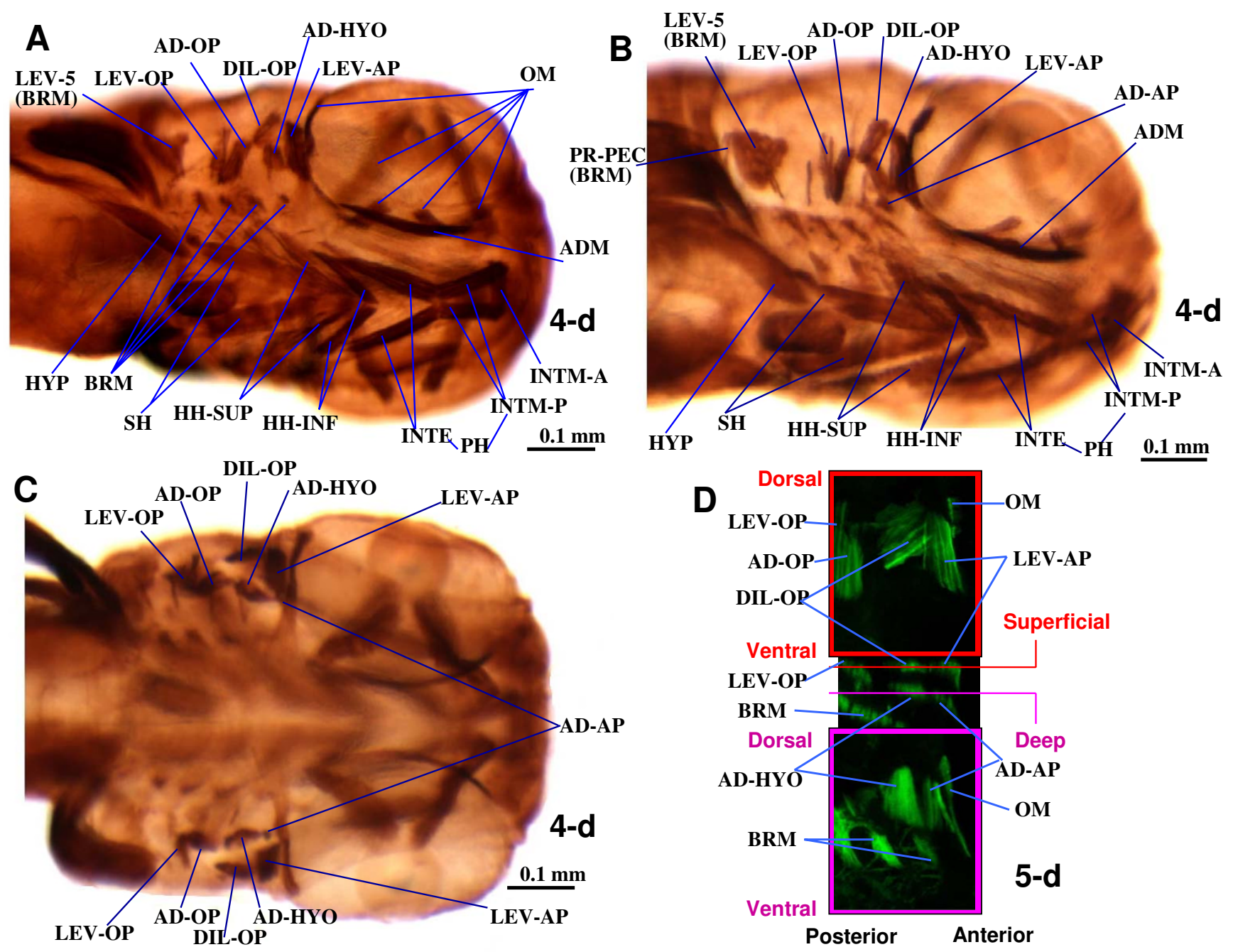

Figure 2

Larval musculature of the zebrafish head. Ventrolateral (A, B, showing different angles and certain distinct structures) and dorsal (C) views of immunohistochemical detection of myosin heavy chain in the cephalic muscles of 4-d zebrafish larvae (3.0 mm TL). Anterior to right. D. Confocal images showing green fluorescent protein (GFP) in the muscles adductor arcus palatini, adductor hyomandibulae, dilatator operculi and levator arcus palatini of a 5-d transgenic zebrafish larva expressing a GFP reporter driven from the muscle-specific alpha-actin promoter. Upper and lower panels: XY confocal optical sections through superficial and deep musculature, respectively. Central panel: $X Z$ confocal reconstruction showing the plains of the confocal XY sections. AD-AP, adductor arcus palatini; AD-HYO, adductor hyomandibulae; AD-OP, adductor operculi; ADM, adductor mandibulae; BRM, branchial muscles; DIL-OP, dilatator operculi; HH-INF, hyoideus inferior; HH-SUP, hyoideus superior; HYP, hypaxialis; INTE, interhyoideus; INTM-A, INTM-P, intermandibularis anterior and posterior; LEV-AP, levator arcus palatini; LEV-OP, levator operculi; LEV-5, levator arcus branchialis 5; OM, ocular muscles; PR-H, protractor hyoideus; PR-PEC, protractor pectoralis; $\mathrm{SH}$, sternohyoideus.

as with the depression of the mandible [38]. The overall configuration of the intermandibularis anterior remains rather unchanged during development. In adults this muscle connects the two dentary bones, thus joining the two mandibles (Figs. 2A, B, 3A and 5B, C; Table 1).

As described in 5 and 6-d larvae [3,8-10], in the 4 and 9-d larvae observed the adductor mandibulae is constituted by a single mass of fibers (Fig. 2A, B). However, in the 14 and 24-d larvae examined, three different adductor mandibulae portions can be recognized (Fig. 3A, B and data not shown): they seemingly correspond to the adductor mandibulae A2, the A $\omega$, and the A0/A1-OST of adults (of Diogo and Chardon [39]; Fig. 5A, B). In 35-d juveniles there is apparent separation between the adductor mandibulae A1-OST and the A0, the fibers of the former being 
Table I: Brief summary of the mandibular (man), hyoid (hyo) and hypobranchial (hyp) muscles found in the adult zebrafish, their attachments and main functions.

\begin{tabular}{|c|c|c|c|}
\hline Name & Origin & Insertion & Function \\
\hline $\begin{array}{l}\text { Intermandibularis anterior } \\
\text { (man) }\end{array}$ & dentary bone (mandible) & $\begin{array}{l}\text { dentary bone of other side of body } \\
\text { (mandible) }\end{array}$ & joins the two mandibles \\
\hline $\begin{array}{l}\text { Protractor hyoideus (man }+ \\
\text { hyo: intermandibularis posterior }+ \\
\text { interhyoideus) }\end{array}$ & $\begin{array}{l}\text { ventral and dorsal portions: } \\
\text { ventromesial surface of dentary } \\
\text { bone (mandible) }\end{array}$ & $\begin{array}{l}\text { ventral portion: anterior } \\
\text { ceratohyal and ventral hypohyal; } \\
\text { dorsal portion: anterior ceratohyal } \\
\text { (hyoid arch) }\end{array}$ & $\begin{array}{l}\text { mainly elevation of hyoid bars, as } \\
\text { well as depression of mandible } \\
\text { (mouth opening) }\end{array}$ \\
\hline $\begin{array}{l}\text { Adductor mandibulae A2 } \\
\text { (man) }\end{array}$ & $\begin{array}{l}\text { preopercle, hyomandibula and } \\
\text { metapterygoid (suspensorium) }\end{array}$ & coronomeckelian bone (mandible) & $\begin{array}{l}\text { the adductor mandibulae complex } \\
\text { is mainly related with mouth } \\
\text { closure, but the maxillary } \\
\text { component A0 can also play a } \\
\text { central role in the mouth } \\
\text { protrusion mechanisms of the } \\
\text { zebrafish (see text) }\end{array}$ \\
\hline $\begin{array}{l}\text { Adductor mandibulae Al - } \\
\text { OST (man) }\end{array}$ & $\begin{array}{l}\text { preopercle and quadrate } \\
\text { (suspensorium) }\end{array}$ & $\begin{array}{l}\text { angulo-articular and dentary bone } \\
\text { (mandible) }\end{array}$ & \\
\hline $\begin{array}{l}\text { Adductor mandibulae AO } \\
\text { (man) }\end{array}$ & $\begin{array}{l}\text { preopercle and quadrate } \\
\text { (suspensorium) }\end{array}$ & maxilla (upper jaw) & \\
\hline $\begin{array}{l}\text { Adductor mandibulae } \mathbf{A} \omega \\
(\mathrm{man})\end{array}$ & $\begin{array}{l}\text { mesial surface of angulo-articular } \\
\text { and dentary bone (mandible) }\end{array}$ & tendon of adductor mandibulae A2 & \\
\hline Levator arcus palatini (man) & sphenotic (neurocranium) & $\begin{array}{l}\text { metapterygoid and hyomandibula } \\
\text { (suspensorium) }\end{array}$ & suspensorial elevation/abduction \\
\hline Dilatator operculi (man) & $\begin{array}{l}\text { frontal and pterotic } \\
\text { (neurocranium) and hyomandibula } \\
\text { (suspensorium) }\end{array}$ & anterodorsal surface of opercle & opercular abduction (opening) \\
\hline Hyohyoideus inferior (hyo) & anterior ceratohyals (hyoid arch) & $\begin{array}{l}\text { mesial aponeurosis, meeting its } \\
\text { contralateral counterpart }\end{array}$ & $\begin{array}{l}\text { adduction of the hyoid arch (see } \\
\text { text) }\end{array}$ \\
\hline Hyohyoideus abductor (hyo) & first branchiostegal ray & $\begin{array}{l}\text { mesial aponeurosis, meeting its } \\
\text { contralateral counterpart }\end{array}$ & $\begin{array}{l}\text { expansion of branchiostegal } \\
\text { membrane }\end{array}$ \\
\hline Hyohyoidei adductores (hyo) & opercle and subopercle & branchiostegal rays & $\begin{array}{l}\text { constriction of branchiostegal } \\
\text { membrane }\end{array}$ \\
\hline Adductor operculi (hyo) & pterotic (neurocranium) & posterodorsal surface of opercle & opercular adduction (closure) \\
\hline Adductor arcus palatini (hyo) & parasphenoid (neurocranium) & $\begin{array}{l}\text { mesial sides of hyomandibula, } \\
\text { metapterygoid and entopterygoid } \\
\text { (suspensorium) }\end{array}$ & suspensorial adduction \\
\hline $\begin{array}{l}\text { Adductor hyomandibulae } \mathbf{X} \\
\text { (hyo) }\end{array}$ & parasphenoid (neurocranium) & $\begin{array}{l}\text { mesial side of hyomandibula } \\
\text { (suspensorium) }\end{array}$ & hyomandibular adduction \\
\hline Levator operculi (hyo) & $\begin{array}{l}\text { ventrolateral margin of pterotic } \\
\text { (neurocranium) }\end{array}$ & dorsomesial edge of opercle & $\begin{array}{l}\text { jaw depression (its force of } \\
\text { contraction is transmitted through } \\
\text { the opercular series and the } \\
\text { interoperculo-mandibular ligament } \\
\text { to the lower jaw: see text) }\end{array}$ \\
\hline Sternohyoideus (hyp) & $\begin{array}{l}\text { anterior region of cleithrum } \\
\text { (pectoral girdle) }\end{array}$ & $\begin{array}{l}\text { urohyal (associated with hyoid } \\
\text { arch) }\end{array}$ & $\begin{array}{l}\text { plays a major role in hyoid } \\
\text { depression, and, through a series } \\
\text { of mechanical linkages, in mouth } \\
\text { opening and suspensorial } \\
\text { abduction }\end{array}$ \\
\hline
\end{tabular}

more horizontally oriented and those of the latter being more anterodorsally oriented and inserting on the maxilla (Fig. 4A, compare with Fig. 5A). In adults, these two portions are well-differentiated (Fig. 5A). The overall configuration of the adult adductor mandibulae, divided into four portions, is thus rather different from the undivided adductor mandibulae found in early larvae. In adults, the adductor mandibulae A0 runs from the preopercle and quadrate to the maxilla (Fig. 5A). The adductor mandibulae A1-OST, mesial to the A0, runs from the preopercle and quadrate to the posterodorsal margin of the mandi- ble, namely to the angulo-articular and the dentary bones (Fig. 5A, B). The adductor mandibulae A2 (Fig. 5A, B) is mesial to the A1-OST and connects the preopercle, hyomandibula and metapterygoid to the small coronomeckelian bone lodged on the mesial surface of the mandible. The adductor mandibulae A $\omega$ attaches anteriorly on the mesial surface of the angulo-articular and dentary bones and posteriorly on the tendon of the A2 (Fig. 5B). As its name indicates, the adductor mandibulae is mainly related with the adduction of the mandible (Table 1 ). However, it should be noted that since the adult AO is 

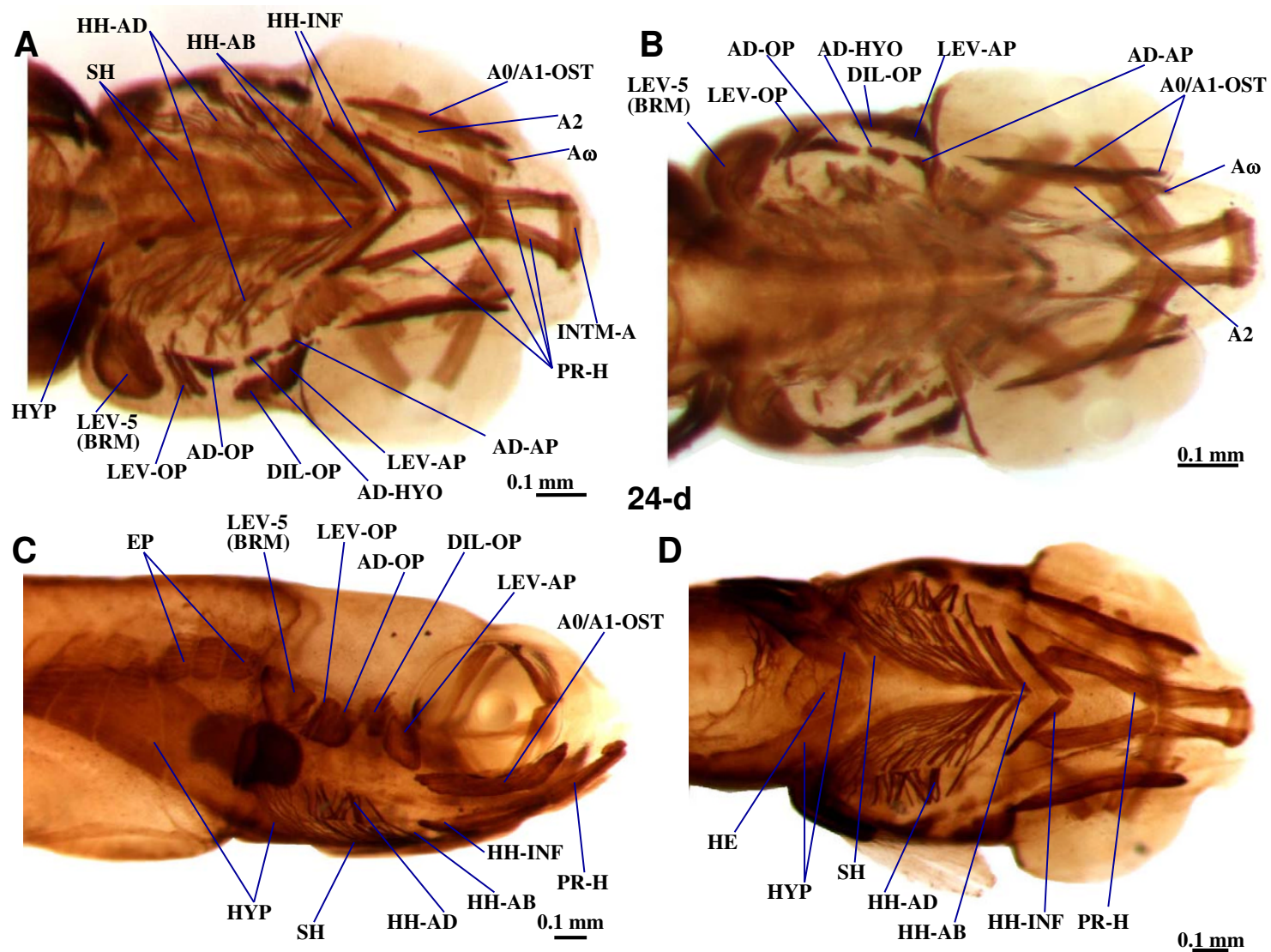

\begin{abstract}
Figure 3
Late larval musculature of zebrafish head. Ventral $(\mathbf{A})$ and dorsal $(\mathbf{B})$ views of the cephalic muscles of 24-d zebrafish larvae $(6.0 \mathrm{~mm}$ TL) and lateral (C) and ventral (D) views of the cephalic muscles and of the anterior portion of the body musculature of 24-d zebrafish larvae (6.9 mm TL). A0, AI-OST, A2, A0, AW, sections A0, Al-OST, A2, A0 and A 1 of adductor mandibulae complex; AD-AP, adductor arcus palatini; AD-HYO, adductor hyomandibulae; AD-OP, adductor operculi; BRM, branchial muscle; DIL-OP, dilatator operculi; EP, epaxialis; HE, heart; HH-AB, hyoideus abductor; $H H-A D$, hyoidei adductores; HH-INF, hyoideus inferior; HYP, hypaxialis; INTM-A, intermandibularis anterior; LEV-AP, levator arcus palatini; LEV-OP, levator operculi; LEV-5, levator arcus branchialis 5; PR-H, protractor hyoideus; PR-H-D, PR-H-D, dorsal and ventral parts of protractor hyoideus; $\mathrm{SH}$, sternohyoideus.
\end{abstract}

attached on the maxilla and not on the mandible, it does not directly drive mandibular adduction. It is instead directly associated with adduction of the maxilla, and thus of the upper jaw, participating in the peculiar mechanisms of mouth protraction/retraction found in the zebrafish and other extant cypriniforms $[11,20,14-16,39,40]$. Thus, the larval adductor mandibulae undergoes splitting to generate different portions of diverse function in the adult.

Each of the two dorsal mandibular muscles of the zebrafish, the levator arcus palatini and dilatator operculi, remains undivided throughout the ontogenetic stages observed (Figs. 2, 3, 4 and 5A). In adults the levator arcus palatini (Fig. 5A) connects the sphenotic to the metapterygoid and hyomandibula and promotes the elevation/ abduction of the suspensorium (a structural complex formed by the hyomandibula, quadrate and pterygoid bones) [38]. The dilatator operculi is lateral to the levator arcus palatini and connects the frontal, pterotic and hyomandibula to the anterodorsal surface of the opercle; it is mainly associated with opercular abduction (Fig. 5A; Table 1).

\section{Hyoid musculature}

Five paired hyoid muscles are formed in the first four days of development: the interhyoideus, the hyohyoideus, the adductor hyomandibulae, the adductor operculi, and the 

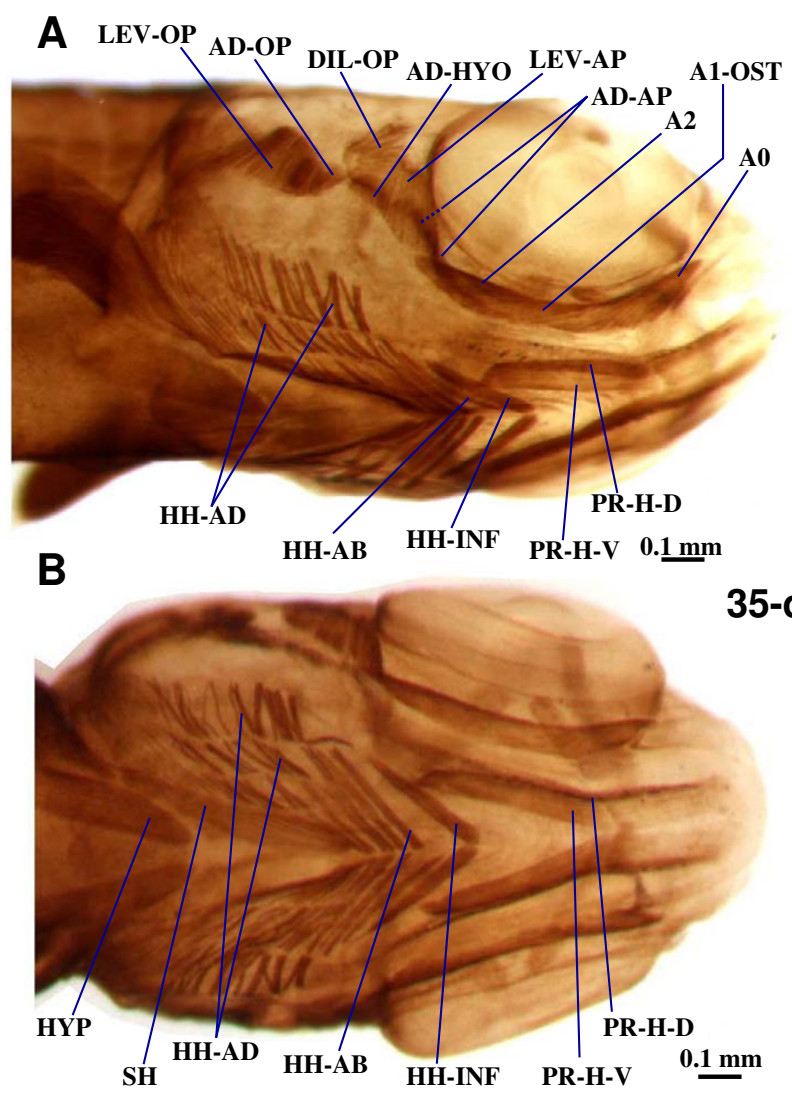

\section{Figure 4}

Juvenile musculature of zebrafish head. Ventrolateral (A) and ventral (B) views of the cephalic muscles of 35-d zebrafish larvae (7.4 mm TL). A0, AI-OST, A2, sections A0, AI-OST, and A2 of adductor mandibulae complex; AD-AP, adductor arcus palatini; AD-HYO, adductor hyomandibulae; AD-OP, adductor operculi; DIL-OP, dilatator operculi; $\mathrm{HH}$ $A B$, hyoideus abductor; $\mathrm{HH}-\mathrm{AD}$, hyoidei adductores; $\mathrm{HH}$ INF, hyoideus inferior; HYP, hypaxialis; LEV-AP, levator arcus palatini; LEV-OP, levator operculi; PR-H-D, PR-H-D, dorsal and ventral parts of protractor hyoideus; $\mathrm{SH}$, sternohyoideus.

levator operculi. The interhyoideus and hyohyoideus appear at $58 \mathrm{hpf}$, the adductor hyomandibulae and adductor operculi at $68 \mathrm{hpf}$, and the levator operculi at 85 hpf [3]. These five muscles, innervated by the VIIth nerve, are found in the larvae, juveniles and adults examined in the present work (Figs. 2, 3, 4 and 5A, C). As mentioned above, in the zebrafish, as in most other teleosts, the interhyoideus becomes associated with the intermandibularis posterior, forming the protractor hyoideus.

As in most other teleosts, in the adult zebrafish the hyohyoideus is innervated by the VIIth nerve, indicating its second arch origin [[3,13,38,40]; data not shown]. Hyohyoideus is divided into three paired structures: the hyohyoideus inferior runs from the anterior ceratohyals to a mesial aponeurosis in which it meets its contralateral counterpart; the hyohyoideus abductor runs from the first branchiostegal ray to a mesial aponeurosis that is attached by means of two thin tendons to the ventral hypohyals and in which it meets its contralateral counterpart; the hyohyoidei adductores connects the branchiostegal rays, the opercle and the subopercle of a single side of the fish (Fig. 5C; Table 1). As stated by Stiassny [38] "there is little commentary in the literature regarding the function of the hyohyoideus inferior but adduction of the hyoid bar is suggested by its position and presumed line of action". Regarding the hyohyoideus abductor and hyohyoidei adductores, which are often considered as parts of a hyohyoideus superior, they are usually associated with the expansion and constriction of the branchiostegal membranes, respectively (Fig. 5C; Table 1). A reference point that is often used to distinguish the hyohyoideus abductor and the hyohyoidei adductores is the position with respect to the most mesial branchiostegal ray: the hyohyoideus abductor is mesial to it and the hyohyoidei adductores lateral (Fig. 5C) [13]. At 9, 14, 24 and 35-d, the hyohyoideus is already separated into three portions that appear to correspond to the hyohyoideus inferior, hyohyoideus abductor and hyohyoidei adductores in adults (Figs. 3, 4, 5C and data not shown). In the 4-d larvae examined, the hyohyoideus is clearly divided into an anterior part, the hyohyoideus inferior, and a posterior part, named here hyohyoideus superior, but it is unclear if this latter is already differentiated into hyohyoideus abductor and hyohyoidei adductores (Figs. 2A, B and data not shown). In some zebrafish specimens, ossification of the branchiostegal rays (dermal bones directly derived from connective tissue) occurs by 4 -d while in others it occurs later; it is thus likely that some 4-d larvae already have a hyohyoideus superior divided into hyohyoideus abductor and hyohyoidei adductores (separated by the most mesial branchiostegal ray) and others not [2].

The dorsal hyoid muscles adductor operculi and levator operculi are well separated throughout the zebrafish stages examined (Figs. 2, 3, 4 and 5A). The adductor operculi of adults lies mesial to the levator operculi and connects the pterotic to the posterodorsal surface of the opercle (Fig. 5A; Table 1). As its name indicates, it is mainly associated with opercular adduction (i.e. closure) [38]. The adult levator operculi runs from the ventrolateral margin of the pterotic to the dorsomesial edge of the opercle (see Fig. 5A; Table 1). The action of the levator operculi of teleosts is usually related to a peculiar mechanism mediating lower jaw depression via the so-called 'four-bar linkage system' in which the force of contraction of this muscle is transmitted through the opercular series (opercle, preopercle and/or interopercle) and the interoperculo-mandibular ligament to the lower jaw [38]. Our 

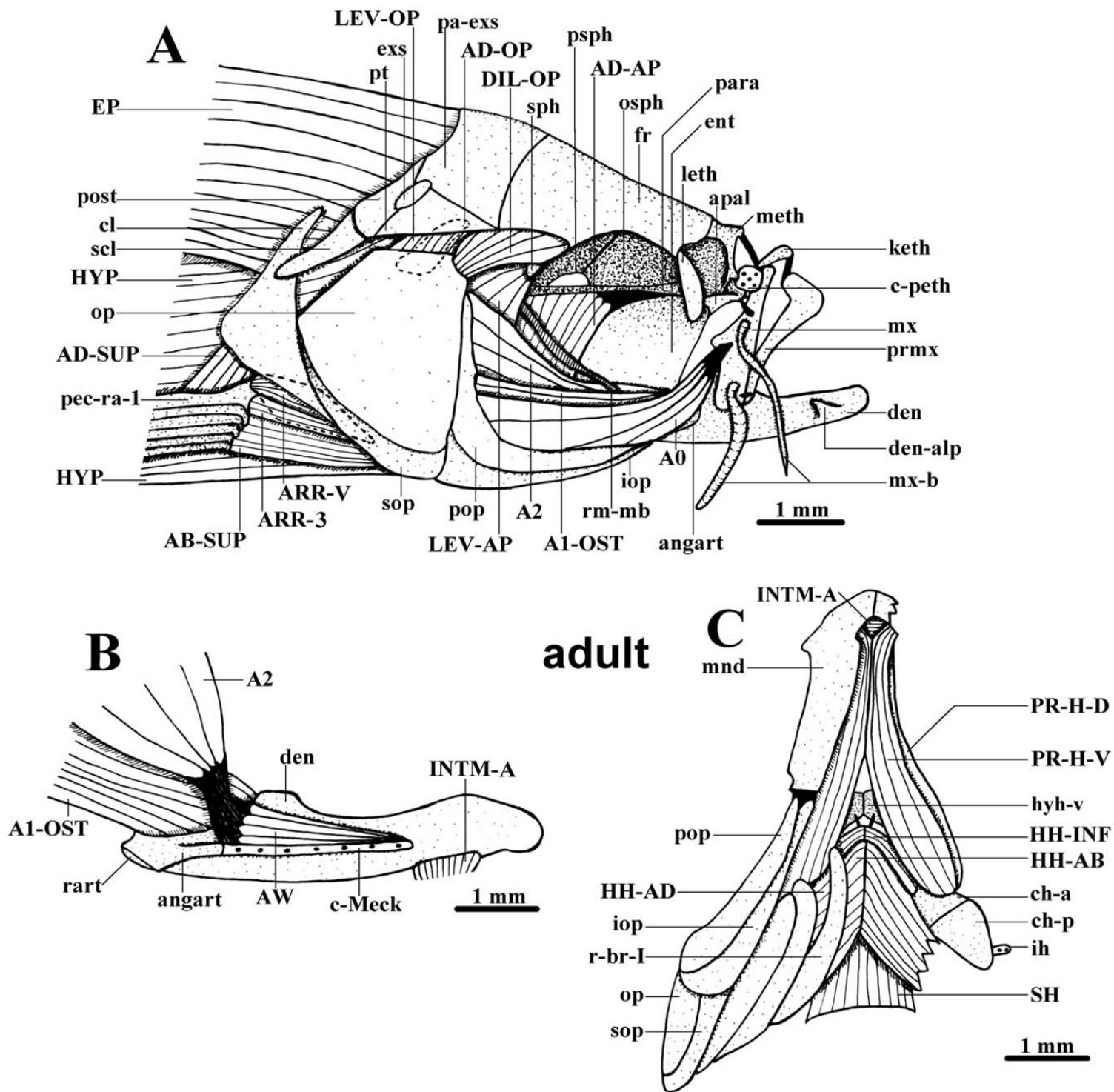

Figure 5

Adult cranial musculature. A. Lateral view of the cranial cephalic muscles and surrounding skeletal structures of an adult zebrafish (45.I mm TL). B. Mesial view of the left mandible and adductor mandibulae of an adult zebrafish (45.I mm TL), part of the anterior intermandibularis is also shown, the adductor mandibulae A0 was removed. C. Ventral view of the cephalic muscles and surrounding skeletal structures of an adult zebrafish (45.1 $\mathrm{mm} \mathrm{TL}$ ), on the right side a portion of the hyohyoidei adductores, as well as of the mandible, was cut, and the opercle, interopercle, subopercle and preopercle are not represented. A0, AI-OST, A2, AW, sections A0, AI-OST, A2 and A $\omega$ of the adductor mandibulae; AB-SUP, abductor superficialis; AD-AP, adductor arcus palatini; AD-OP, adductor operculi; AD-SUP, adductor superficialis; angart, angulo-articular; apal, autopalatine; ARR-3, arrector 3; ARR-V, arrector ventralis; c-Meck, Meckelian cartilage; c-peth, pre-ethmoid cartilage; ch-a, ch-p, anterior and posterior ceratohyals; cl, cleithrum; den, dentary bone; den-alp, anterolateral process of dentary bone; DIL-OP, dilatator operculi; ent, entopterygoid; EP, epaxialis; exs, extrascapular; fr, frontal; $\mathrm{HH}-\mathrm{AB}$, hyohyoideus abductor; HH-AD, hyohyoidei adductores; HH-INF, hyohyoideus inferior; hyh-v, ventral hypohyal; HYP, hypaxialis; ih, interhyal; INTM-A, intermandibularis anterior; iop, interopercle; keth, kinethmoid; leth, lateral-ethmoid; LEV-AP, levator arcus palatini; LEV-OP, levator operculi; meth, mesethmoid; mnd, mandible; mx, maxilla; mx-b, maxillary barbel; op, opercle; osph, orbitosphenoid; pa-exs, parietoextrascapular; para, parasphenoid; pec-ra-I, pectoral ray I; pop, preopercle; post, posttemporal; prmx, premaxilla; PR-H-D, $\mathrm{PR}-\mathrm{H}-\mathrm{V}$, dorsal and ventral sections of protractor hyoidei; psph, pterosphenoid; pt, pterotic; r-br-I, branchiostegal ray I; rart, retroarticular; rm-mb, mesial branch of ramus mandibularis; scl, supracleithrum; $\mathrm{SH}$, sternohyoideus; sop, subopercle; sph, sphenotic. 
observations of zebrafish larvae and adults indicate that the action of the zebrafish levator operculi is similar to that found in other teleosts.

In addition to the five hyoid muscles described by Schilling and Kimmel [3], we observed in all specimens examined (from 4-d larvae to adults), an additional muscle, the adductor arcus palatini (Figs. 2B, C, 3A-B, 4A and 5A) [13]. In the other bony fishes in which this muscle is found, it is hyoid arch derived (see Tables 2, 3, 4, 5, 6, 7). In the adult zebrafish, the adductor arcus palatini runs from the neurocranium to the mesial sides of the hyomandibula, metapterygoid and entopterygoid (Fig. 5A; Table 1). It is anterior to, and broader than, the adductor hyomandibulae, which connects the neurocranium to the mesial margin of the hyomandibula. To confirm this observation, we examined 5-d alpha-actin GFP transgenic zebrafish larvae by confocal microscopy. The adductor arcus palatini and the adductor hyomandibulae effectively constitute separate muscles, which are often hidden behind the dilator operculi and levator arcus palatini in whole mount preparations (Fig. 2D). Although in the larval and juvenile specimens observed in the present work the adductor arcus palatini and adductor hyomandibulae lie close to each other, they also constitute distinct muscles (Figs. 2, 3A-B, and 4A). Our observations indicate that the action of the zebrafish adductor arcus palatini is somewhat similar to that found in other teleosts: it promotes the adduction of the suspensorium (a structural complex formed by the hyomandibula, quadrate and pterygoid bones), thus acting as the antagonist of the levator arcus palatini (see above) [38].

\section{Hypobranchial musculature}

There is a single hypobranchial muscle in the zebrafish: the sternohyoideus ([12]; Figs. 2A, B, 3A and 5C). In the study of Schilling and Kimmel [3] this muscle, innervated by the anterior branches of the occipito-spinal nerves, appeared at $53 \mathrm{hpf}$. In early stages the sternohyoideus is markedly divided longitudinally, its right and left parts only meeting anteriorly, near the region of the hyohyoideus inferior (Figs. 2A, B). As described in zebrafish and several other teleosts, each of these parts consists of three myomeres separated by two myocommata $[3,12,13]$. In older stages of development the right and left parts become closer to each other; in adults they are connected mesially throughout their lengths, forming a large coneshaped structure that originates from the anterior region of the cleithrum and passes dorsally to the hyohyoideus inferior and hyohyoideus abductor in order to attach on the urohyal (Fig. 5C; Table 1). The sternohyoideus plays a major role in hyoid depression, and, through a series of mechanical linkages, in mouth opening and suspensorial abduction $[8,38]$. As in numerous other teleosts $[12,13]$, the posterior portion of the sternohyoideus lies near the anterior attachment of the hypaxialis (ventral body musculature) on the pectoral girdle (Figs. 2A, B, 3A, and 4B), the fibers of the former being sometimes associated posteriorly with fibers of the latter (e.g. Fig. 2B). Therefore, the contraction of the hypaxialis during a feeding strike may not only prevent the origin of the sternohyoideus from moving anteriorly, but also facilitate a greater ventral displacement of the hyoid (= hyoid depression) by pulling the posterior portion of the sternohyoideus backwards [8]. In zebrafish larvae the anterior portion of the epaxial and hypaxial body muscles extend anteriorly to attachments on the back of the skull and pectoral girdle, thus lying near to, and eventually associating with, the head muscles (e.g. Fig. 3C, D). This configuration is also seen in the adult zebrafish (Fig. 5A).

\section{Discussion \\ Homologies of the zebrafish mandibular, hyoid and hypobranchial muscles}

As raised in the Background section, a major question addressed is the present paper is: to which muscles of other osteichthyans do the mandibular, hyoid and hypobranchial muscles of the zebrafish correspond? Here we add the zebrafish to the up-dated compilation of the extant data and discussion of the development, evolution and homologies of cranial muscles within various major groups of Osteichthyes [36]. Our discussion provides a starting point for investigating the identity and homologies between zebrafish mandibular, hyoid and hypobranchial muscles and the muscles found in other osteichthyans (Tables 2, 3, 4, 5, 6).

Mandibular muscles (Tables 2, 3)

According to Edgeworth [12], in numerous gnathostomes the embryonic mandibular muscle plate gives rise dorsally to the premyogenic condensation constrictor dorsalis and medially to the premyogenic condensation adductor mandibulae. To this can be added, ventrally, the intermandibularis (Tables 2, 3). Molecular developmental studies have supported the existence of the constrictor dorsalis in the cranial region of teleosts $[7,35]$. Expression of Engrailed genes marks muscle cells associated with the dorsal region of the first arch $[7,35]$. The constrictor dorsalis was plesiomorphically found in osteichthyans and then independently lost in dipnoans and amphibians (Tables 2, 3; see fig. 1). The constrictor dorsalis that gave rise to the levator arcus palatini and dilatator operculi in zebrafish and other actinopterygians is therefore homologous with the constrictor dorsalis that gives rise to e.g. the levator arcus palatini in extant sarcopterygian fishes such as Latimeria and to the protractor pterygoidei and levator pterygoidei in certain amniotes (Tables 2, 3).

Regarding the ventral portion of the mandibular muscle plate, in all major osteichthyan groups listed in Tables 2 


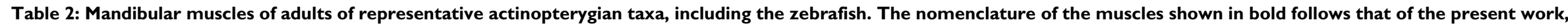

mand." meaning adductor mandibulae, In order to facilitate comparisons, in some cases certain names often used by other authors to designate a certain muscle/bundle are given in

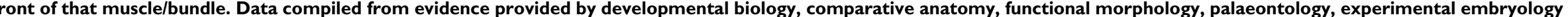
and molecular biology, innervation and phylogeny (for more details, see text).

\begin{tabular}{|c|c|c|c|c|}
\hline $\begin{array}{l}\text { Probable plesiomorphic } \\
\text { osteichthyan condition }\end{array}$ & $\begin{array}{l}\text { Cladistia: Polypterus bichir } \\
\text { (Bichir) }\end{array}$ & $\begin{array}{l}\text { Chondrostei: Psephurus } \\
\text { gladius (Chinese } \\
\text { swordfish) }\end{array}$ & $\begin{array}{l}\text { Ginglymodi: Lepisosteus } \\
\text { osseus (Longnose gar) }\end{array}$ & $\begin{array}{l}\text { Halecomorphi: Amia calvo } \\
\text { (Bowfin) }\end{array}$ \\
\hline $\begin{array}{l}\text { Intermandibularis } \\
\text { posterior }\left(*^{\text {intermandibul }}\right. \\
\text { aris anterior and posterior } \\
\text { plesiomorphically present } \\
\text { in osteichthyans? See text) }\end{array}$ & Intermandibularis & Intermandibularis & Intermandibularis & $\begin{array}{l}\text { Intermandibularis } \\
\text { posterior }\end{array}$ \\
\hline $\begin{array}{l}\text { Intermandibularis } \\
\text { anterior (*see cell above) }\end{array}$ & ----- & ---- & ---- & $\begin{array}{l}\text { Intermandibularis } \\
\text { anterior }\end{array}$ \\
\hline ----- & ----- & ----- & ----- & ---- \\
\hline
\end{tabular}

Ad. mand. A3'

Ad. mand. A3' (ad. mand. of e.g. Lauder [69])

Ad. mand. A3"

Ad. mand. A2

----

$$
\text { ----- }
$$$$
\underset{\infty}{\stackrel{+}{\infty}}
$$

$\infty$ Ad. mand. A

Ad. mand. Aw

Levator arcus palatini

\section{Ad. mand. A $\omega$}

Levator arcus palatini mand. pterygoideus of e.g.

Lauder [69])

Ad. mand. A2 (ad. mand. posterolateral of e.g.

Lauder [69])

$-\cdot-$

$-\cdot-$

\section{$---\cdot$} $----$

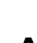

Ad. mand. A2 (ad. mand of e.g. Carroll and Wainwright [72])

-----

----

$-$

----

Protractor

hyomandibulae

(*seemingly originated

from the portion of the

hyoid muscle plate from

which originate the

adductor arcus palatini

and dilatator operculi of

other actinopterygians)

---- (*dilatator operculi

element, but see cell

above)
Ad. mand. A3'

(preorbitalis superficialis

of e.g. Lauder [69]

Ad. mand. A3"

Ad. mand. A3'

(preorbitalis profundus of

e.g. Lauder [69])

Ad. mand. A2 (ad. mand. Ad. mand. A2

posterolateral of e.g.

Lauder [69])

Palatomandibularis

minor and major

-.--.

$---$

$-\cdot-$

Levator arcus palatini

Ad. mand. A3"

$---\cdot$

Levator maxillae superioris 3 and 4

$-\cdot--$

Ad. mand. A $\omega$

$\begin{array}{ll}\text { Teleostei - basal: Elops } & \text { Teleostei - clupeocephalan: } \\ \text { saurus (Ladyfish) } & \text { Danio rerio (Zebrafish) }\end{array}$
saurus (Ladyfish)

Danio rerio (Zebrafish)

Intermandibularis posterior (*forming, together with

interhyoideus, the

protractor hyoideus)

Intermandibularis

anterior

Protractor hyoideus

(*including

intermandibularis

posterior and

interhyoideus; it is thus

derived from both the

mandibular and hyoid

muscle plates)

Ad. mand. A2

Intermandibularis

posterior (*see cell on the

left)

Intermandibularis

anterior

Protractor hyoideus

(*see cell on the left)

Levator arcus palatini 


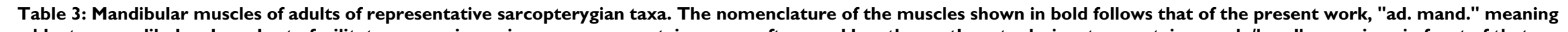

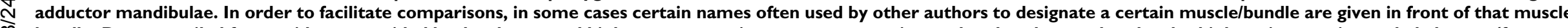

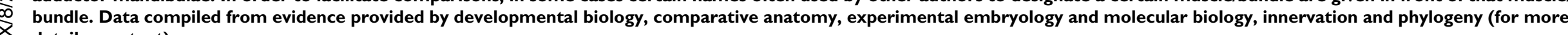
details, see text).

$\begin{array}{ll}\begin{array}{l}\text { Probable plesiomorphic } \\ \text { osteichthyan condition }\end{array} & \begin{array}{l}\text { Actinistia: Latimeria } \\ \text { chalumnae (Coelacanth) }\end{array}\end{array}$

Dipnoi: Lepidosiren

Amphibia: Ambystoma

Reptilia: Timon lepidus

Mammalia: Rattus

Mammalia: Homo sapiens

paradoxa (South American ordinarium (Michoacan

(Ocellated lizard)

norvegicus

(Human)

\begin{tabular}{lllll}
\hline $\begin{array}{l}\text { Intermandibularis } \\
\text { posterior (*see Table 2) }\end{array}$ & $\begin{array}{l}\text { Intermandibularis } \\
\text { posterior }\end{array}$ & Intermandibularis & $\begin{array}{l}\text { Intermandibularis } \\
\text { posterior }\end{array}$ & $\begin{array}{l}\text { Intermandibularis } \\
\text { posterior }\end{array}$ \\
\hdashline-- & -- & -- & -- \\
$\begin{array}{l}\text { Intermandibularis } \\
\text { anterior (*see Table 2) }\end{array}$ & $\begin{array}{l}\text { Intermandibularis } \\
\text { anterior }\end{array}$ & --- & $\begin{array}{l}\text { Intermandibularis } \\
\text { anterior }\end{array}$ & $\begin{array}{l}\text { Intermandibularis } \\
\text { anterior }\end{array}$
\end{tabular}

Ad. mand. A3'

\section{Ad. mand. A3' (ad.}

mand. 'moyen' of e.g.

Ad. mand. A3' (ad.

Millot and Anthony [24])

mand. anterior of e.g.

Bemis and Lauder [50])

Ad. mand. A3"

Ad. mand. A3" (ad. man.
'profond' of e.g. Millot and Anthony [24])
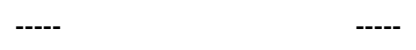

$---$

anterior

anterior

Ad. mand. A3'

(pseudotemporalis

Ad. mand. A3

[73])

Ad. mand. A3"

(pseudotemporalis

anterior of e.g. lordansky

[73])

$-\cdot-\cdot$

$---$

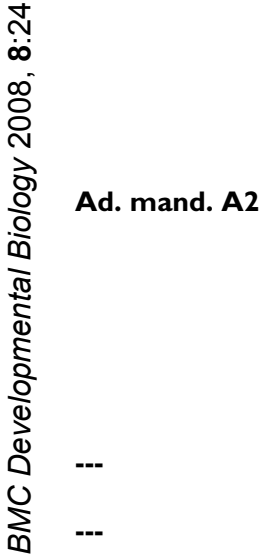

Ad. mand. A2 (ad. mand. 'superficiel' of e.g. Millot and Anthony [24])

Ad. mand. A2 (part of ad. mand. posterior of $e$ Bemis and Lauder [50])

Ad. mand. A2 (ad. mand. externus of e.g. lordansky

Ad. mand. A2 (ad. mand. externus of e.g. Abdala and Moro [74])

superficialis of e.g. Abdala and Moro [74])

Ad. mand. A3" (pseudotemporalis profundus of e.g. Abdala and Moro [74])

Pterygomandibularis (*seemingly derived from mesial portion of ad.

mand.)

Mylohyoideus
$(*$ mylohyoideus and
digastricus anterior of rats
derived from
intermandibularis

intermandibularis

posterior, see e.g. Jarvik

[53])

Digastricus anterior

(*see cell above)

Intermandibularis

anterior (transversus

mandibularis of Greene

[83])

--- (*but see below)

Digastricus anterior

--- (*but see below)

--- (*but see below)

Pterygoideus medialis (*derived from mesial

portion of ad. mand. of

other tetrapods; seemingly

corresponding to $\mathrm{A}^{\prime} / \mathrm{A} 3^{\prime \prime}$

and/or

pterygomandibularis of e.g.

lizards: see e.g. Saban [79])

Masseter (*masseter,

pterygoideus lateralis and

temporalis of mammals

seemingly derived from

lateral, and eventually also

medial, portions of ad.

mand. of other tetrapods

$[12,46,79,80])$

Temporalis (*see cell

above)

Pterygoideus lateralis

(*see cell above)

Temporalis

$--$ 


\begin{tabular}{|c|c|c|c|c|c|c|}
\hline $\begin{array}{l}---- \\
\end{array}$ & ----- & $\begin{array}{l}\text { Ad. mand. A2-PVM } \\
\text { (part of ad. mand. } \\
\text { posterior of e.g. Bemis and } \\
\text { Lauder [50]) }\end{array}$ & $\begin{array}{l}\text { Ad. mand. A2-PVM (ad. } \\
\text { mand. posterior of e.g. } \\
\text { lordansky [73]) }\end{array}$ & $\begin{array}{l}\text { Ad. mand. A2-PVM (ad. } \\
\text { mand. posterior of e.g. } \\
\text { Abdala and Moro [74]) }\end{array}$ & $\begin{array}{l}\text { Tensor veli palatini } \\
\left({ }^{*} \text { tensor veli palatini and }\right. \\
\text { tensor tympani of } \\
\text { mammals seemingly } \\
\text { derived from ad. mand. } \\
\text { A2-PVM of other } \\
\text { tetrapods }[12,79])\end{array}$ & Tensor veli palatini \\
\hline-- & --- & -- & --- & --- & $\begin{array}{l}\text { Tensor tympani (*see } \\
\text { cell above) }\end{array}$ & Tensor tympani \\
\hline ---- & ---- & $\begin{array}{l}\text { Retractor anguli oris } \\
\text { (*seemingly derived from } \\
\text { lateral portion of ad. } \\
\text { mand.) }\end{array}$ & ----- & ---- & --- & --- \\
\hline ---- & ---- & ---- & ----- & $\begin{array}{l}\text { Levator anguli oris } \\
\text { (*present, somewhat } \\
\text { mixed with A2; seemingly } \\
\text { derived from lateral } \\
\text { portion of ad. mand, it may } \\
\text { eventually be derived/ } \\
\text { modified from the } \\
\text { retractor anguli oris, or at } \\
\text { least from the portion of } \\
\text { the mandibular muscle } \\
\text { plate originating that } \\
\text { muscle in other } \\
\text { osteichthyan taxa) }\end{array}$ & -- & -- \\
\hline Ad. mand. A $\omega$ & $\begin{array}{l}\text { Ad. mand. A } \omega \\
\text { (intramandibular adductor } \\
\text { of e.g. Lauder [75]) }\end{array}$ & ----- & ----- & $\begin{array}{l}\text { Ad. mand. A } \omega \text { (*in Timon } \\
\text { the ad. mand. has an } \\
\text { anteroventral section that } \\
\text { is lodged in the 'adductor } \\
\text { fossa' and that is very } \\
\text { similar to the A } \omega \text { of other } \\
\text { osteichthyan taxa: is this } \\
\text { section homologous to the } \\
\text { A } \omega \text { of those taxa? [36]) }\end{array}$ & -- & -- \\
\hline Levator arcus palatini & Levator arcus palatini & ----- & ---- & $\begin{array}{l}\text { Levator pterygoidei }(* i t \\
\text { may well be derived/ } \\
\text { modified from the levator } \\
\text { arcus palatini, or at least } \\
\text { from the portion of the } \\
\text { mandibular muscle plate } \\
\text { originating that muscle in } \\
\text { other osteichthyan taxa) }\end{array}$ & -- & -- \\
\hline ----- & ---- & ----- & ----- & $\begin{array}{l}\text { Protractor pterygoidei } \\
\text { (*same as cell above) }\end{array}$ & -- & --- \\
\hline
\end{tabular}




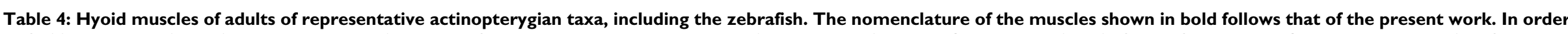

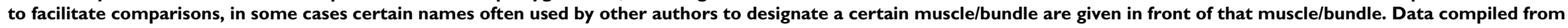
evidence provided by developmental biology, comparative anatomy, experimental embryology and molecular biology, innervation and phylogeny (for more details, see text).

\begin{tabular}{|c|c|c|c|c|c|c|}
\hline $\begin{array}{l}\text { Probable plesiomorphic } \\
\text { osteichthyan condition }\end{array}$ & $\begin{array}{l}\text { Cladistia: Polypterus bichir } \\
\text { (Bichir) }\end{array}$ & $\begin{array}{l}\text { Chondrostei: Psephurus } \\
\text { gladius (Chinese swordfish) }\end{array}$ & $\begin{array}{l}\text { Ginglymodi: Lepisosteus } \\
\text { osseus (Longnose gar) }\end{array}$ & $\begin{array}{l}\text { Halecomorphi: Amia calva } \\
\text { (Bowfin) }\end{array}$ & $\begin{array}{l}\text { Teleostei - basal: Elops } \\
\text { saurus (Ladyfish) }\end{array}$ & $\begin{array}{l}\text { Teleostei - clupeocephalan: } \\
\text { Danio rerio (Zebrafish) }\end{array}$ \\
\hline Interhyoideus & Interhyoideus & Interhyoideus & Interhyoideus & Interhyoideus & $\begin{array}{l}\text { Interhyoideus ('forming, } \\
\text { together with } \\
\text { intermandibularis } \\
\text { posterior, the protractor } \\
\text { hyoideus: see Table 2) }\end{array}$ & $\begin{array}{l}\text { Interhyoideus (*see cell } \\
\text { on the left) }\end{array}$ \\
\hline ----- & Hyohyoideus & Hyohyoideus & Hyohyoideus & Hyohyoideus inferior & Hyohyoideus inferior & Hyohyoideus inferior \\
\hline ----- & ---- & ---- & ---- & $\begin{array}{l}\text { Hyohyoideus abductor } \\
\text { (*often considered as part } \\
\text { of a hyohyoideus } \\
\text { superior) }\end{array}$ & $\begin{array}{l}\text { Hyohyoideus abductor } \\
\text { (*see cell on the left) }\end{array}$ & $\begin{array}{l}\text { Hyohyoideus abductor } \\
\text { (*see cell on the left) }\end{array}$ \\
\hline---- & ----- & ----- & ----- & $\begin{array}{l}\text { Hyohyoidei adductores } \\
\text { (*often considered as part } \\
\text { of a hyohyoideus } \\
\text { superior) }\end{array}$ & $\begin{array}{l}\text { Hyohyoidei adductores } \\
\text { (*see cell on the left) }\end{array}$ & $\begin{array}{l}\text { Hyohyoidei adductores } \\
\text { (*see cell on the left) }\end{array}$ \\
\hline Adductor operculi & Adductor operculi & $\begin{array}{l}\text { Adductor operculi } \\
\text { (opercularis of e.g. Carroll } \\
\text { and Wainwright [72]) }\end{array}$ & Adductor operculi & Adductor operculi & Adductor operculi & Adductor operculi \\
\hline $\begin{array}{l}\text { Adductor arcus } \\
\text { palatini }\end{array}$ & $\begin{array}{l}\text { Adductor arcus } \\
\text { palatini }\end{array}$ & $\begin{array}{l}\text { Retractor } \\
\text { hyomandibulae } \\
\text { (*seemingly originated from } \\
\text { the portion of the hyoid } \\
\text { muscle plate from which } \\
\text { originates the adductor } \\
\text { arcus palatini of other } \\
\text { actinopterygians) }\end{array}$ & $\begin{array}{l}\text { Adductor arcus } \\
\text { palatini }\end{array}$ & $\begin{array}{l}\text { Adductor arcus } \\
\text { palatini }\end{array}$ & $\begin{array}{l}\text { Adductor arcus } \\
\text { palatini }\end{array}$ & Adductor arcus palatini \\
\hline----- & ----- & ----- & ---- & ----- & ----- & $\begin{array}{l}\text { 'Adductor } \\
\text { hyomandibulae X' } \\
\text { (*seemingly not } \\
\text { homologous to the } \\
\text { 'adductor hyomandibulae Y' } \\
\text { of Table 5) }\end{array}$ \\
\hline ---- & ----- & ----- & ---- & $\begin{array}{l}\text { Levator operculi } \\
(\text { *seemingly not } \\
\text { homologous to the } \\
\text { 'levator operculi' of Table } \\
5)\end{array}$ & $\begin{array}{l}\text { Levator operculi (*see } \\
\text { cell on the left) }\end{array}$ & $\begin{array}{l}\text { Levator operculi (*see } \\
\text { cell on the left) }\end{array}$ \\
\hline
\end{tabular}


Table 5: Hyoid muscles of adults of representative sarcopterygian taxa. The nomenclature of the muscles shown in bold follows that of the present work. In order to facilitate comparisons, in some cases certain names often used by other authors to designate a certain muscle/bundle are given in front of that muscle/bundle. Data compiled from evidence provided by developmental biology, comparative anatomy, experimental embryology and molecular biology, innervation and phylogeny (for more details, see text).

\begin{tabular}{|c|c|c|c|c|c|c|}
\hline $\begin{array}{l}\text { Probable plesiomorphic } \\
\text { osteichthyan condition }\end{array}$ & $\begin{array}{l}\text { Actinistia: Latimeria } \\
\text { chalumnae (Coelacanth) }\end{array}$ & $\begin{array}{l}\text { Dipnoi: Lepidosiren } \\
\text { paradoxa (South American } \\
\text { lungfish) }\end{array}$ & $\begin{array}{l}\text { Amphibia: Ambystoma } \\
\text { ordinarium (Michoacan } \\
\text { stream salamander) }\end{array}$ & $\begin{array}{l}\text { Reptilia: Timon lepidus } \\
\text { (Ocellated lizard) }\end{array}$ & $\begin{array}{l}\text { Mammalia: Rattus } \\
\text { norvegicus (Norway rat) }\end{array}$ & $\begin{array}{l}\text { Mammalia: Homo } \\
\text { sapiens (Human) }\end{array}$ \\
\hline Interhyoideus & $\begin{array}{l}\text { Interhyoideus } \\
\text { ('géniohyoïdien' plus } \\
\text { "hyohyoïdien' of e.g. Millot } \\
\text { and Anthony [24]) }\end{array}$ & Interhyoideus & $\begin{array}{l}\text { Interhyoideus } \\
\text { (interhyoideus anterior } \\
\text { plus interhyoideus } \\
\text { posterior of e.g. Bauer } \\
\text { [57], and Ericsson and } \\
\text { Olsson [32]) }\end{array}$ & $\begin{array}{l}\text { Interhyoideus } \\
\text { (constrictor colli of e.g. } \\
\text { Herrel et al [76]) }\end{array}$ & $\begin{array}{l}\text { Part of facial muscles } \\
\text { (*facial muscles of } \\
\text { mammals derive mostly } \\
\text { from interhyoideus, but } \\
\text { possibly also from } \\
\text { cervicomandibularis, see } \\
\text { e.g. Lightoller [8I] and } \\
\text { Saban [79) }\end{array}$ & $\begin{array}{l}\text { Part of facial } \\
\text { muscles }\end{array}$ \\
\hline $\begin{array}{l}\text { Adductor arcus } \\
\text { palatini }\end{array}$ & $\begin{array}{l}\text { Adductor arcus } \\
\text { palatini }\end{array}$ & $\begin{array}{l}\text { the hyoid muscle plate } \\
\text { that gives rise to the } \\
\text { levator hyoideus/ } \\
\text { depressor mandibulae } \\
\text { eventually correspond to } \\
\text { that giving rise to the } \\
\text { adductor arcus palatini of } \\
\text { other osteichthyans?) }\end{array}$ & ---- (*see cell on the left) & ---- (*see on the left) & ---- (*see on the left) & ---- (*see on the left) \\
\hline ----- & ---- & Levator hyoideus & $\begin{array}{l}\text { Depressor mandibulae } \\
\text { posterior (*the fibers } \\
\text { corresponding to those of } \\
\text { the levator hyoideus of } \\
\text { dipnoans become also } \\
\text { attached on the mandible, } \\
\text { forming the depressor } \\
\text { mandibulae posterior; the } \\
\text { depressor mandibulae } \\
\text { anterior thus seemingly } \\
\text { corresponds to the } \\
\text { depressor mandibulae of } \\
\text { dipnoans) }\end{array}$ & $\begin{array}{l}\text { Depressor mandibulae } \\
\text { (part) (*the fibers } \\
\text { corresponding to those of } \\
\text { the levator hyoideus of } \\
\text { dipnoans become also } \\
\text { attached on the mandible, } \\
\text { forming part of the } \\
\text { depressor mandibulae) }\end{array}$ & --- (*but see below) & --- (*but see below) \\
\hline ---- & ---- & Depressor mandibulae & $\begin{array}{l}\text { Depressor mandibulae } \\
\text { anterior (*see cell above) }\end{array}$ & $\begin{array}{l}\text { Depressor mandibulae } \\
\text { (part) }(* \text { see cell above) }\end{array}$ & --- (*but see below) & -- (*but see below) \\
\hline
\end{tabular}


Table 5: Hyoid muscles of adults of representative sarcopterygian taxa. The nomenclature of the muscles shown in bold follows that of the present work. In order to facilitate

comparisons, in some cases certain names often used by other authors to designate a certain muscle/bundle are given in front of that muscle/bundle. Data compiled from evidence

provided by developmental biology, comparative anatomy, experimental embryology and molecular biology, innervation and phylogeny (for more details, see text). (Continued)

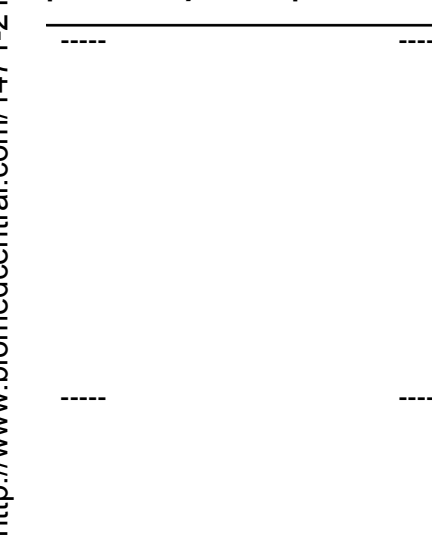

Branchiohyoideus

(branchiohyoideus

externus of e.g.

Edgeworth [12] and

.

from levator hyoideus/

depressor mandibulae)

---- (*as noted by e.g.

Edgeworth [12] the

'branchiohyoideus' of

lizards seemingly

corresponds to the

branchial muscle

subarcualis rectus I of

amphibians, and not to the

hyoid muscle

branchiohyoideus of the

present work)

'Adductor

hyomandibulae $\mathbf{Y}$

(*seemingly not

'adductor hyomandibulae

X' of Table 4)

Adductor operculi

Adductor operculi element in adults, but see

Latimeria's 'levator

operculi' ('seemingly not

homologous to the levator

operculi of Table 4)
Cervicomandibularis

(*seemingly derived from

--- (*but see above)

levator hyoideus/

depressor mandibulae

[12])

Stapedius (*stapedius of mammals derived from levator hyoideus/

depressor mandibulae [ 12

$$
\text { 46, 82]) }
$$

Digastricus posterior

(*digastricus posterior and stylohyoideus of mammals seemingly derived from

levator hyoideus/

depressor mandibulae, and not from interhyoideus:

see e.g. Huber [82])

Stylohyoideus (*see cell above)

---- (*absent as a separate

text)
$--$

\section{Digastricus}

posterior

--- (*but see above)

Stapedius$$
-
$$$$
--
$$$$
---
$$$$
\text { ---- }
$$ 
Table 6: Hypobranchial muscles of adults of representative actinopterygian taxa, including the zebrafish. The nomenclature of the muscles shown in bold follows that of the present work. Data compiled from evidence provided by developmental biology, comparative anatomy, experimental embryology and molecular biology, innervation and phylogeny (for more details, see text).

\begin{tabular}{|c|c|c|c|c|c|c|}
\hline $\begin{array}{l}\text { Probable } \\
\text { plesiomorphic } \\
\text { osteichthyan } \\
\text { condition }\end{array}$ & $\begin{array}{l}\text { Cladistia: } \\
\text { Polypterus bichir } \\
\text { (Bichir) }\end{array}$ & $\begin{array}{l}\text { Chondrostei: } \\
\text { Psephurus gladius } \\
\text { (Chinese } \\
\text { swordfish) }\end{array}$ & $\begin{array}{l}\text { Ginglymodi: } \\
\text { Lepisosteus osseus } \\
\text { (Longnose gar) }\end{array}$ & $\begin{array}{l}\text { Halecomorphi: } \\
\text { Amia calva } \\
\text { (Bowfin) }\end{array}$ & $\begin{array}{l}\text { Teleostei - basal: } \\
\text { Elops saurus } \\
\text { (Ladyfish) }\end{array}$ & $\begin{array}{l}\text { Teleostei- } \\
\text { clupeocephalan: } \\
\text { Danio rerio } \\
\text { (Zebrafish) }\end{array}$ \\
\hline $\begin{array}{l}\text { Coracomandibu } \\
\text { laris }\end{array}$ & $\begin{array}{l}\text { Branchiomandi } \\
\text { bularis (*modified } \\
\text { from } \\
\text { coracomandibulari } \\
\text { s) }\end{array}$ & $\begin{array}{l}\text { Branchiomandi } \\
\text { bularis (*see cell } \\
\text { on the left) }\end{array}$ & ----- & $\begin{array}{l}\text { Branchiomandi } \\
\text { bularis (*see cells } \\
\text { on the left) }\end{array}$ & ----- & ----- \\
\hline Sternohyoideus & Sternohyoideus & Sternohyoideus & Sternohyoideus & Sternohyoideus & Sternohyoideus & Sternohyoideus \\
\hline
\end{tabular}

and 3 it gives rise to the intermandibularis. In adult extant members of Actinistia, Chondrostei, Ginglymodi and Dipnoi the intermandibularis is mainly undivided. Adults of Amia, Latimeria, and numerous amphibian, amniote and teleostean genera, including Danio, exhibit an intermandibularis anterior and an intermandibularis posterior. It is, therefore, difficult to discern if the intermandibularis was divided or not in plesiomorphic adult osteichthyans (Tables 2, 3).

As in the zebrafish, in most teleosts the intermandibularis posterior and interhyoideus form the protractor hyoideus, which is thus derived from the mandibular and hyoid muscle plates (Figs. 2, 3, 4, and 5C). Although a protractor hyoideus is not found in a few teleosts such as Albula and Mormyrus [13,41,42], this muscle was seemingly present in the ancestors of extant teleosts (Table 2). Based on the altered morphology of the protractor hyoideus in morpholino-mediated Hox PG2 (hoxa2b and hoxa2a) knockdown larvae, Hunter and Prince [10] suggested that in the zebrafish "the basihyal (cartilage) may be important for the proper ontogenetic organization" of the intermandibularis posterior and the interhyoideus, and, thus, for the association of their fibers and the formation of the protractor hyoideus. Further studies are needed to check if this is so and if it is a general feature within the Teleostei.

The adductor mandibulae is found in members of all major osteichthyan groups (Tables 2,3 ). The number of divisions of this muscle is highly variable within these groups (Tables 2, 3). As often occurs with other muscles, different names are used in the literature to designate the adductor mandibulae divisions in different osteichthyan taxa, and sometimes within the same taxon. This is a major reason for the historical confusions concerning the homologies and evolution of these divisions within osteichthyans. The names employed in Tables 2, 3, 4, 5, 6, 7 are those often used by researchers working with phylogenetically more plesiomorphic groups. Our observations regarding the development, function and adult configura- tion of the zebrafish adductor mandibulae A2 and A $\omega$ indicate that these sections correspond to the A2 and A $\omega$ found in most major osteichthyan groups. Regarding the zebrafish adductor mandibulae A1-OST and A0, these divisions correspond to adductor mandibulae sections that are exclusively found in ostariophysan teleosts and in cypriniforms, respectively [19,39]. Hernandez et al. [9] stated that the adult zebrafish has an adductor mandibulae A $\omega$ and three further sub-divisions, as we also observe. The adductor mandibulae A1, A2 and A3 of Hernandez et al. probably correspond, respectively, to the A0, A1-OST and A2 of the present study (see Table 2; Figs. 5A, B).

\section{Hyoid muscles (Tables 4, 5)}

Edgeworth [12] suggested that a constrictor hyoideus condensation usually gives rise to dorso-medial and ventral derivatives throughout the major groups of gnathostomes. Two dorso-medial hyoid muscles were seemingly found in plesiomorphic osteichthyans: the adductor arcus palatini and the adductor operculi (Tables 4, 5). These muscles are found in most teleosts, including the zebrafish (Figs. 2B, C, 3, 4, and 5A). A few teleosts lack an adductor operculi (e.g. saccopharyngiforms) [43-45]. Apart from the adductor arcus palatini and the adductor operculi, other dorso-medial hyoid muscles are found in certain living osteichthyans (Tables 4, 5). For example, the zebrafish, as most extant teleosts and the halecomorph Amia, has a muscle levator operculi (Figs. 2, 3, 4, and 5A). Millot and Anthony [24] stated that Latimeria has a 'levator operculi'. However, whether this muscle is homologous to the levator operculi of zebrafish is doubtful for two main reasons. First, the muscles have distinct function: contrary to the zebrafish and other teleosts and to Amia, Latimeria does not have an interoperculo-mandibular ligament and, therefore, does not have an opercular mechanism mediating mandible depression [36]. Second, and more importantly, it is cladistically more parsimonious to consider that these muscles were independently acquired in actinistians and halecostomes (2 steps) than to have one acquisition (in the node leading to osteich- 


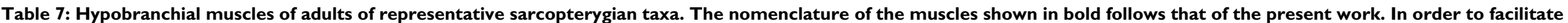
comparisons, in some cases certain names often used by other authors to designate a certain muscle/bundle are given in front of that muscle/bundle. Data compiled from evidence provided by developmental biology, comparative anatomy, experimental embryology and molecular biology, innervation and phylogeny (for more details, see text).

\begin{tabular}{|c|c|c|c|c|c|c|}
\hline $\begin{array}{l}\text { Probable plesiomorphic } \\
\text { osteichthyan condition }\end{array}$ & $\begin{array}{l}\text { Actinistia: Latimeria } \\
\text { chalumnae (Coelacanth) }\end{array}$ & $\begin{array}{l}\text { Dipnoi: Lepidosiren paradoxa } \\
\text { (South American lungfish) }\end{array}$ & $\begin{array}{l}\text { Amphibia: Ambystoma ordinarium (Michoacan } \\
\text { stream salamander) }\end{array}$ & $\begin{array}{l}\text { Reptilia: Timon lepidus } \\
\text { (Ocellated lizard) }\end{array}$ & $\begin{array}{l}\text { Mammalia: Rattus norvegicus } \\
\text { (Norway rat) }\end{array}$ & $\begin{array}{l}\text { Mammalia: Homo } \\
\text { sapiens (Human) }\end{array}$ \\
\hline Coracomandibularis & Coracomandibularis & $\begin{array}{l}\text { Coracomandibularis } \\
\text { (geniothoracicus of e.g. } \\
\text { Miyake et al. [34]) }\end{array}$ & $\begin{array}{l}\text { Geniohyoideus }\left({ }^{*} \text { geniohyoideus does not }\right. \\
\text { correspond directly to coracomandibularis of } \\
\text { bony fishes, because this latter also gave rise to } \\
\text { tetrapod muscles as e.g. genioglossus and } \\
\text { hyoglossus; so in this case we can accept to use } \\
\text { the name geniohyoideus, due to its consensual } \\
\text { use within anatomists working with tetrapods) }\end{array}$ & $\begin{array}{l}\text { Geniohyoideus } \\
\text { (geniohyoideus and/or at least } \\
\text { part of mandibulohyoideus of } \\
\text { e.g. Edgeworth [112] and } \\
\text { Herrel et al. [76]) }\end{array}$ & Geniohyoideus & Geniohyoideus \\
\hline ---- & ---- & ---- & $\begin{array}{l}\text { Genioglossus (*according to e.g. Edgeworth } \\
\text { [12] the genioglossus of salamanders such as } \\
\text { Ambystoma is derived from the } \\
\text { coracomandibularis) }\end{array}$ & $\begin{array}{l}\text { Genioglossus (*according to } \\
\text { e.g. Edgeworth [12] the } \\
\text { genioglossus of lizards such as } \\
\text { Timon is derived from the } \\
\text { coracomandibularis) }\end{array}$ & Genioglossus & Genioglossus \\
\hline ---- & ----- & ----- & $\begin{array}{l}\text { Hyoglossus }(* \text { the statements of Edgeworth } \\
\text { [12] concerning the origin of this muscle in } \\
\text { salamanders such as Ambystoma are somewhat } \\
\text { confuse: in his page } 196 \text { he states that it } \\
\text { originates from the sternohyoideus but in his } \\
\text { page } 211 \text { I he seems to indicate that, as in other } \\
\text { amphibians as well as in amniotes, it derives } \\
\text { from the coracomandibularis) }\end{array}$ & $\begin{array}{l}\text { Hyoglossus (*according to } \\
\text { e.g. Edgeworth [12] the } \\
\text { hyoglossus of lizards such as } \\
\text { Timon is derived from the } \\
\text { coracomandibularis) }\end{array}$ & Hyoglossus & Hyoglossus \\
\hline--- & --- & --- & --- & --- & $\begin{array}{l}\text { Styloglossus }(* \text { derived from } \\
\text { hyoglossus, see e.g. Edgeworth } \\
\text { [12] and Saban [79]) }\end{array}$ & Styloglossus \\
\hline --- & --- & --- & -- & --- & -- & $\begin{array}{l}\text { Palatoglossus } \\
\text { (*seemingly derived } \\
\text { from styloglossus, see } \\
\text { e.g. Edgeworth [12]) }\end{array}$ \\
\hline Sternohyoideus & Sternohyoideus & $\begin{array}{l}\text { Sternohyoideus (rectus } \\
\text { cervicis of e.g. Bemis and } \\
\text { Lauder [50]) }\end{array}$ & $\begin{array}{l}\text { Sternohyoideus (rectus cervicis of e.g. } \\
\text { Lauder and Shaffer [77]) }\end{array}$ & $\begin{array}{l}\text { Sternohyoideus (rectus } \\
\text { cervicis of e.g. Kardong [46]) }\end{array}$ & Sternohyoideus & Sternohyoideus \\
\hline--- & --- & --- & --- & --- & $\begin{array}{l}\text { Sternothyroideus } \\
\left({ }^{*} \text { sternothyroideus and }\right. \\
\text { thyrohyoideus seemingly } \\
\text { derived from sternohyoideus, } \\
\text { see e.g. Edgeworth [12], Saban } \\
\text { [79], and Kardong [46]) }\end{array}$ & Sternothyroideus \\
\hline --- & --- & --- & --- & --- & $\begin{array}{l}\text { Thyrohyoideus (*see cell } \\
\text { above) }\end{array}$ & Thyrohyoideus \\
\hline ---- & ----- & ---- & $\begin{array}{l}\text { Omohyoideus (*seemingly derived from the } \\
\text { sternohyoideus) }\end{array}$ & Omohyoideus & Omohyoideus & Omohyoideus \\
\hline
\end{tabular}


thyans) and various independent losses (at least in nonactinistian sarcopterygians, in cladistians, in chondrosteans and in ginglymodians) (see Fig. 1). On balance, our view is that the 'levator operculi' of Latimeria is unlikely to be homologous with the levator operculi of the zebrafish and other teleosts and of Amia (see Tables 4, 5). Similar reasoning applies to the 'adductor hyomandibulae' of Latimeria and to the adductor hyomandibulae found in the zebrafish and certain other teleosts (see below). However, further studies, and particularly more detailed palaeontological data, are needed to clarify the exact taxonomic distribution of these muscles within osteichthyans. The dipnoan 'levator operculi' illustrated by Kardong [46], which may correspond to the adductor operculi of other bony fishes but forms, in extant adult dipnoans, a continuous sheet of fibers together with other cranial muscles $[12,21,23,47-51]$, seemingly corresponds to the constrictor operculi of Bemis and Lauder [50]. Therefore, the levator operculi found in the zebrafish, most other teleosts and Amia is seemingly not homologous with any of the individual cranial muscles of other extant osteichthyans: it probably derived evolutionarily from the adductor operculi at the node leading to the Halecostomi (Fig. 1, Table 4) [36].

Apart from the adductor arcus palatini, some osteichthyans have other muscles connecting the neurocranium to the palatoquadrate/suspensorium and promoting the adduction of these latter structures. This is the case in zebrafish, which exhibit an adductor arcus palatini and an adductor hyomandibulae according to Winterbottom's nomenclature [13]. There is much confusion in the literature concerning these muscles. As explained by Winterbottom [13], in most teleosts there is a single muscle connecting the neurocranium to the mesial surface of the suspensorium and thus acting to adduct this latter structure. Winterbottom opted to designate this muscle 'adductor arcus palatini' and not 'adductor hyomandibulae' because the latter name becomes inappropriate in the numerous taxa in which this muscle is expanded anteriorly along the floor of the orbit and attaches on elements of the suspensorium other than the hyomandibula, for example the metapterygoid and/or entopterygoid (as is the case in the adult zebrafish). He therefore used the name 'adductor hyomandibulae' to designate a muscle that is only found in a few osteichthyans (one of them being the zebrafish) and that is usually situated posteriorly to his adductor arcus palatini, connecting the neurocranium to the mesial surface of the hyomandibula. This nomenclature is followed in the present study (Tables 4, $5)$. At least some of the muscles 'adductor hyomandibulae' of osteichthyans are non-homologous, as they may originate "1) either from the posterior region of the adductor arcus palatini or 2) from the anterior fibers of the adductor operculi" [13]. This is for instance the case of the 'adductor hyomandibulae' found in Latimeria [24] and in various teleosts (Tables 4, 5; see above). In order to distinguish the 'adductor hyomandibulae' of the zebrafish from the 'adductor hyomandibulae' of Latimeria, these muscles are designated in Tables 4, 5 as 'adductor hyomandibulae $\mathrm{X}^{\prime}$ and 'adductor hyomandibulae $\mathrm{Y}^{\prime}$ ', respectively.

Examples of dorso-medial hyoid muscles that are not found in the zebrafish, but which are present in other osteichthyans, are the levator hyoideus and the depressor mandibulae, which seemingly gave rise to the stylohyoideus, digastricus posterior, stapedius, and possibly part of the facial muscles of mammals (Table 5). The levator hyoideus is usually related with the elevation of the posterodorsal portion of the ceratohyal, whereas the depressor mandibulae is usually related with the opening of the mouth $[49,50]$. The levator hyoideus is found in at least some developmental stages of extant dipnoans and of numerous extant tetrapods [12]. The depressor mandibulae of extant dipnoans such as Lepidosiren and Protopterus seems to be homologous with part of the depressor mandibulae of tetrapods (see Table 7). Interestingly, works such as Köntges and Lumsden [30] have shown that in tetrapod taxa such as birds the posterior region of the mandible to which the depressor mandibulae attaches is constituted by neural crest derivatives of the hyoid arch, and not of the mandibular arch. This is one of the several examples given by these authors to illustrate the highly constrained pattern of cranial skeletomuscular connectivity found in these tetrapods: each rhombomeric neural crest population remains coherent throughout ontogeny, forming both the connective tissues of specific muscles and their respective attachment sites onto the neuro- and viscerocranium. It would be interesting, therefore, to investigate if the depressor mandibulae of dipnoans such as Protopterus and Lepidosiren also attaches in a region of the mandible constituted by neural crest derivatives of the hyoid arch. If future investigation shows that the mandible of extant non-dipnoan bony fishes is exclusively formed by mandibular neural crest derivatives, this would indicate that the presence of a depressor mandibulae in tetrapods and dipnoans might be related with an evolutionary change in which hyoid neural crest derivatives have become incorporated in the formation of the lower jaw.

The plesiomorphic condition for osteichthyans is seemingly that in which the ventral portion of the hyoid muscle plate gives rise to a single division, designated here as interhyoideus (Tables 4, 5). In most extant actinopterygians part of the interhyoideus separates into a distinct muscle during development, the hyohyoideus (Table 4). In adult zebrafish, as in most other teleosts, the hyohyoideus is divided into hyohyoideus inferior, hyohyoideus 
abductor and hyohyoidei adductores (Fig. 5C; Tables 4, 5 ). Beyond teleosts, the presence of these three divisions is only found in the extant halecomorph Amia (Tables 4, $5)$. An independent hyohyoideus in seemingly missing in extant Sarcopterygii (Table 5). Although there are some sarcopterygians in which the portion of the hyoid muscle plate that gives rise to the interhyoideus and hyohyoideus in actinopterygians eventually becomes somewhat divided into bundles that resemble these two muscles, these bundles remain deeply mixed throughout all developmental stages. This is the case of the interhyoideus anterior and interhyoideus posterior of various salamanders (Table 5) [52-58]. It is seemingly also the case of the "géniohyoïdien" and "hyohyoïdien" described by Millot and Anthony [24] in Latimeria (Table 5). Further studies are needed to determine whether splitting of interhyoideus evolved repeatedly in osteichthyans.

\section{Hypobranchial muscles (Tables 6, 7)}

The plesiomorphic condition for osteichthyans is seemingly that found in adult members of Actinistia and Dipnoi, which exhibit two hypobranchial muscles: a coracomandibularis and a sternohyoideus (Tables 6, 7). In extant cladistians, chondrosteans and halecomorphs the coracomandibularis is modified into a peculiar muscle branchiomandibularis that connects the branchial arches to the mandible. A coracomandibularis/branchiomandibularis is missing in living ginglymodians and teleosts, including the zebrafish (Table 6). Therefore, contrary to what is sometimes stated in the literature, the geniohyoideus of tetrapods does not correspond to the zebrafish protractor hyoidei, nor to any of its constituents (i.e. the intermandibularis posterior and the interhyoideus) (Tables 6, 7). The absence of a coracomandibularis/branchiomandibularis in living ginglymodians and in teleosts is seemingly due to a secondary loss [59-61]. In extant tetrapods, there are various hypobranchial muscles that are not found in other extant osteichthyans, for example the omohyoideus, sternothyroideus, thyrohyoideus and the specialized glossal muscles related with the movements of the tongue (Table 7) [12,46,53,54,62-68].

\section{Ontogeny and Phylogeny}

Another major question addressed by this paper is: does the development of the mandibular, hyoid and hypobranchial muscles in the zebrafish correspond to the evolution of these muscles within the Osteichthyes? Our analysis shows that only in certain cases is this true. For example, based on our previous cladistic analysis [36], within osteichthyan evolutionary history the mandibular muscles intermandibularis anterior, intermandibularis posterior, adductor mandibulae and levator arcus palatini were seemingly present in basal osteichthyans; the dilatator operculi was apparently only acquired later in evolution, being exclusively found in actinopterygians (Table
2). However, according to Schilling and Kimmel, sarcomeric myosin expression (SME; i.e. contractile function) of the dilatator operculi, levator arcus palatini, intermandibularis anterior and intermandibularis posterior begins ontogenetically at about the same time in the zebrafish, i.e. at $62 \mathrm{hpf}$ (the adductor mandibulae appears at $53 \mathrm{hpf}$ ) [3]. In contrast, the development of the zebrafish adductor mandibulae divisions does seem to follow the order in which these divisions were acquired in evolution. The adductor mandibulae A2 and A $\omega$ were acquired first in evolution, being plesiomorphically found in osteichthyans; the adductor mandibulae A1-OST and A0 were acquired later, namely in the nodes leading to ostariophysans and to cypriniforms, respectively (Tables 2, 3) [36]. During zebrafish development, the adductor mandibulae A2 and A $\omega$ also form earlier, being already separated in the 9-d larvae examined. The adductor mandibulae A1OST and A0 were only distinguished in 35 -d juveniles and adults.

The order in which the hyoid muscles were acquired in evolution is: first, the interhyoideus, adductor operculi and adductor arcus palatini (plesiomorphically found in osteichthyans); then, the hyohyoideus (only found in extant actinopterygians); then, the levator operculi (only found in extant halecomorphs and teleosts); and, lastly, the adductor hyomandibulae X (found in some teleosts, seemingly not homologous with the adductor hyomandibulae Y of Latimeria) (Table 4) [36]. According to Schilling and Kimmel, in the zebrafish SME of the interhyoideus and hyohyoideus begins at $58 \mathrm{hpf}$, of the adductor operculi and adductor hyomandibulae at 68 hpf, and of the levator operculi at $85 \mathrm{hpf}$ [3]. Thus, as in phylogeny, in the zebrafish SME of the levator operculi begins later than SME of the interhyoideus, the hyohyoideus and the adductor operculi. However, unlike phylogeny, SME of the zebrafish hyohyoideus begins earlier than the adductor operculi.

The single hypobranchial muscle in the zebrafish, the sternohyoideus, begins SME at $53 \mathrm{hpf}$ and consists of left and right parts [3]. We show that these parts gradually fuse during later development. Interestingly, in adult basal actinopterygians, the sternohyoideus is longitudinally divided into left and right parts that remain physically separate [69]. This plesiomorphic configuration was, however, modified in the node leading to the Teleostei: in adult teleosts, including the zebrafish, the sternohyoideus is a cone-shaped structure in which the left and right parts are hardly distinguished from each other. Thus, during zebrafish development the overall configuration of the sternohyoideus becomes modified in a manner that resembles the changes that occurred in actinopterygian evolution. 
The examples above show that although in certain cases there is a correspondence between the ontogeny of the mandibular, hyoid and hypobranchial muscles in the zebrafish and the evolution of these muscles within Osteichthyes, this is not always the case. This also applies to other zebrafish head muscles, as well as certain cartilages and bones. For example, as shown in Figure 2A, B, in 4-d zebrafish larvae the levator arcus branchialis 5 is already much broader than the other branchial muscles, prior to the splitting of the adductor mandibulae into different sections. However, in evolution the hypertrophy of the levator arcus branchialis 5 occurred only in the node leading to cypriniforms, much later than the division of the adductor mandibulae in different sections (Fig. 1; Table 2) [36]. The modification of the muscle levator arcus branchialis 5, as well as of the skeletal structure that is moved by this muscle, the ceratobranchial 5 , is related with the specialized feeding mechanisms of cypriniforms [2,3,11-18]). Ceratobranchial 5 bears teeth and ossifies earlier than other ceratobranchials in cypriniforms, a case of 'acceleration' of development [3]. Such coordinated ontogenetic timing changes may ensure proper size relationships between skeletal and myological structures.

\section{Conclusion: zebrafish as a case study}

The zebrafish is the most studied model organism among osteichthyan fishes, and is often taken as a 'good representative' of teleosts, of actinopterygians, and even of bony fishes in developmental and molecular studies. But, regarding its mandibular, hyoid and hypobranchial muscles, to what extent is it appropriate to consider the zebrafish as an appropriate 'representative' of these groups?

As can be seen in Tables 2, 3, 4, 5, 6, 7, all of the 13 mandibular, hyoid and hypobranchial muscles found in the adult zebrafish (intermandibularis anterior, protractor hyoideus, adductor mandibulae, levator arcus palatini, dilatator operculi, hyohyoideus inferior, hyohyoideus abductor, hyohyoidei adductores, adductor arcus palatini, adductor hyomandibulae, adductor operculi, levator operculi, and sternohyoideus) are found in at least some other living teleosts, and all except the protractor hyoideus are found in at least some non-teleost extant actinopterygians. Therefore, although the zebrafish occupies a rather derived phylogenetic position within the Actinopterygii and even within the Teleostei (Fig. 1), with respect to these muscles, it seems justified to consider the zebrafish as a potential representative of these two groups. Moreover, of these 13 muscles, about half are found in at least some extant sarcopterygian fishes (six muscles; namely the intermandibularis anterior, adductor mandibulae, levator arcus palatini, adductor arcus palatini, adductor operculi, and sternohyoideus). About a quarter can be confidently identified in at least some extant adult tetrapods (three muscles; the intermandibularis anterior, adductor mandibulae, and sternohyoideus). Therefore, among the cranial muscles discussed in this paper, these three latter muscles are particularly appropriate for direct comparisons between the results obtained in molecular and developmental studies of the zebrafish and the data obtained from model tetrapod organisms from clades such as Amphibia and/or Amniota. The information provided here forms a solid basis for future analyses on zebrafish cranial muscles and for a proper comparison between these muscles and those found in other osteichthyans.

\section{Methods}

King's wild type or $\mathrm{Tg}$ (acta1:GFP) [70] zebrafish were reared according to Westerfield [71]. 4-d (96 hpf, 10 larvae, mean total length $3.2 \mathrm{~mm}$ ), 9-d (216 hpf, 10 larvae, mean total length $4.0 \mathrm{~mm}$ ), 14-d (336 hpf, 10 larvae, mean total length $4.5 \mathrm{~mm}$ ), 24-d (576 hpf, 10 larvae mean total length $6.5 \mathrm{~mm}$ ) and 35-d (986 hpf, 10 juveniles, mean total length $7.4 \mathrm{~mm}$ ) were killed and fixed in $4 \%$ paraformaldehyde. Larval or juvenile fish were bleached in $1 \% \mathrm{H}_{2} \mathrm{O}_{2} 5 \%$ formamide solution to remove pigment, processed for immunohistochemistry with antimyosin heavy chain antibody A4.1025 as previously described [3], and viewed and photographed on a Zeiss Axiophot. Adult specimens (10, from the collection of the Museo Nacional de Ciencias Naturales de Madrid, about 1-year-old, mean length $45.2 \mathrm{~mm}$ ) were alcohol-preserved. Dissections and morphological drawings of adult specimens were made using a Wild M5 dissecting microscope equipped with a camera lucida. The nomenclature used to designate the skeletal and muscular structures follows that of Diogo [36]. The phylogenetic framework for the discussions provided in the present paper is based on the results of a recent cladistic analysis of osteichthyan higher-level phylogeny including 356 phylogenetic osteological and myological characters and 80 extant and fossil terminal taxa (Fig. 1) [36].

\section{Authors' contributions}

$\mathrm{RD}$ and SMH designed the study, carried out the experiments, analyzed the data and drafted the manuscript. The configuration of adult zebrafish cranial muscles was analysed by RD. YH analysed alpha-actin GFP transgenic zebrafish larvae and obtained the confocal images. All the work was done in the MRC Centre for Developmental Neurobiology and the Randall Division for Cell and Molecular Biophysics. All authors read and approved the final manuscript.

\section{Acknowledgements}

We would like to thank T. Abreu, A. Zanata, F. Meunier, D. Adriaens, F. Wagemans, C. Oliveira, M. de Pinna, P. Skelton, F. Poyato-Ariza, T. Grande, H. Gebhardt, M. Ebach, A. Wyss, J. Waters, G. Cuny, L. Cavin, F. Santini, J. Briggs, L. Gahagan, M. Gayet, J. Alves-Gomes, G. Lecointre, L. Soares- 
Porto, P. Bockmann, B. Hall, F. Galis, T. Roberts, G. Arratia, L. Taverne, E. Trajano, B. Kapoor, C. Ferraris, M. Brito, R. Reis, R. Winterbottom, C. Borden, M. Chardon, P. Vandewalle, I. Doadrio, B. Wood, B. Richmond, R. Knight, S. Devoto, V. Abdala and many other colleagues for their helpful advice and assistance and for their discussions on osteichthyan anatomy, functional morphology, phylogeny and/or evolution. R. Diogo received financial support from a postdoctoral grant of the 'Fondation Duesberg' (University of Liège) and from a 'Presidential Merit Fellowship' (George Washington University). S.M. Hughes is an MRC Scientist with Programme grant support.

\section{References}

I. Nelson JS: Fishes of the world 4th edition. New York: John Wiley \& Sons; 2006.

2. Cubbage CC, Mabee PM: Development of the cranium and paired fins in the zebrafish Danio rerio (Ostariophysi, Cyprinidae). J Morphol 1996, 229:121-160.

3. Schilling TF, Kimmel CB: Musculoskeletal patterning in the pharyngeal segments of the zebrafish. Development 1997, 1 24:2945-2960

4. Nüsslein-Volhard C, Gilmour DT, Dahm R: Introduction: zebrafish as a system to study development and organogenesis. In Zebrafish: a practical approach Edited by: Nüsslein-Volhard C, Dahm R. New York: Oxford University Press; 2002: I-5.

5. Schilling TF: The morphology of larval and adult zebrafish. In Zebrafish: a practical approach Edited by: Nüsslein-Volhard C, Dahm R. New York: Oxford University Press; 2002:59-94.

6. Easter SS, Nicola GN: The development of vision in the zebrafish (Danio rerio). Dev Biol 1996, 180:646-663.

7. Hatta K, Schilling TF, Bremiller R, Kimmel CB: Specification of jaw muscle identity in zebrafish: correlation with engrailedhomeoprotein expression. Science 1990, 250:802-805.

8. Hernandez LP, Barresi MJF, Devoto SH: Functional morphology and developmental biology of zebrafish: reciprocal illumination from an unlikely couple. Integ Comp Biol 2002, 42:222-23I.

9. Hernandez LP, Patterson SE, Devoto SH: The development of muscle fiber type identity in zebrafish cranial muscles. Anat Embryol 2005, 209:323-334.

10. Hunter MP, Prince VE: Zebrafish Hox Paralogue group 2 genes function redundantly as selector genes to pattern the second pharyngeal arch. Dev Biol 2002, 247:367-389.

II. Takahasi N: On the homology of the cranial muscles of the cypriniform fishes. J Morphol 1925, 40: I- 109.

12. Edgeworth FH: The cranial muscles of vertebrates Cambridge: University press; 1935.

13. Winterbottom $R$ : A descriptive synonymy of the striated muscles of the Teleostei. Proc Acad Nat Sci (Phil) 1974, I 25:225-3 17.

14. Vandewalle P: Des formes aux fonctions: une étude de morphologie fonctionnelle et comparée chez trois poissons cyprinidés. In PhD thesis University of Liège, Zoology Department; 1975.

15. Vandewalle P: Particularités anatomiques de la tête de deux Poissons Cyprinidés Barbus barbus (L.) et Leuciscus leuciscus (L). Bull Acad R Belg 1977, 5:469-479.

16. Vandewalle P: Analise des mouvements potentiels de la region cephalique du Goujon, Gobio gobio (L.) (Poisson, Cyprinidae). Cybium 1978, 3:15-33.

17. Howes GJ: The anatomy and relationships of the cyprinid fish Luciobrama macrocephalus (Lacepède). Bull Br Mus Nat Hist (Zool) 1978, 34:I-64.

18. Howes G]: Notes on the anatomy of Macrochirichthys macrochirus (Valenciennes), with comments on the Cultrinae (Pisces, Cyprinidae). Bull Br Mus Nat Hist (Zool) 1844, 36: 147-200.

19. Gosline WA: Jaw musculature configuration in some higher teleostean fishes. Copeia 1986, 1986:705-713.

20. Gosline WA: Two patterns of differentiation in the jaw musculature of teleostean fishes. I Zool (Lond) 1989, 21 8:649-66।.

21. Luther $A$ : Über die vom $\mathbf{N}$ trigeminus versorgte muskulatur des Ganoiden and Dipneusten. Acta Soc Scient Fenn 19/3, 4I:I-72.

22. Luther $A$ : Über die vom $\mathbf{N}$ trigeminus versorgte muskulatur der Amphibien, mit einem vergleichenden aublick über deu adductor mandibulae der Gnathostomen, und cinem beitrag zum verständnis der organisation der anurenlarven. Acta Soc Scient Fenn 19|4, 44: I-I5I.

23. Kesteven $\mathrm{HL}$ : The evolution of the skull and the cephalic muscles. Mem Aust Mus 1945, 8: I-36I.

24. Millot J, Anthony J: Anatomie de Latimeria chalumnae, I - squelette, muscles, et formation de soutiens Paris: CNRS; 1958.

25. Le Lièvre C, Le Douarin NM: Mesenchymal derivatives of the neural crest: analysis of chimaeric quail and chick embryos. J Embryol Exp Morphol 1975, 34: I25-I54.

26. Noden DM: The embryonic origins of avian cephalic and cervical muscles and associated connective tissues. Am J Anat 1983, 168:257-276.

27. Noden DM: Craniofacial development: new views on old problems. Anat Rec 1984, 208: I-13.

28. Noden DM: Patterning of avian craniofacial muscles. Dev Biol 1986, II 6:347-356

29. Couly GF, Coltey PM, LeDouarin NM: The developmental fate of the cephalic mesoderm in quail-chick chimeras. Development 1992, II 4:I-15.

30. Köntges G, Lumsden A: Rhombencephalic neural crest segmentation is preserved throughout craniofacial ontogeny. Development 1996, I22:3229-3242.

31. Olsson L, Falck P, Lopez K, Cobb J, Hanken J: Cranial neural crest cells contribute to connective tissue in cranial muscles in the anuran amphibian, Bombina orientalis. Dev Biol 2001, 237:354-367.

32. Ericsson R, Olsson L: Patterns of spatial and temporal visceral arch muscle development in the Mexican axolotl (Ambystoma mexicanum). J Morphol 2004, 26 I: I3 I-I 40.

33. Ericsson R, Cerny R, Falck P, Olsson L: Role of cranial neural crest cells in visceral arch muscle positioning and morphogenesis in the Mexican axolotl (Ambystoma mexicanum). Dev Dynam 2004, 23 I :237-247

34. Miyake T, McEachran JD, Hall BK: Edgeworth's legacy of cranial muscle development with an analysis of muscles in the ventral gill arch region of batoid fishes (Chondrichthyes: Batoidea). J Morphol 1992, 2 I 2:2 13-256

35. Hatta K, Bremiller R, Westerfield M, Kimmel CB: Diversity of expression of engrailed-like antigens in zebrafish. Development 1991, I | 2:821-832

36. Diogo R: On the origin and evolution of higher-clades: osteology, myology, phylogeny and macroevolution of bony fishes and the rise of tetrapods Enfield: Science Publishers in press.

37. Diogo R, Vandewalle P: Review of superficial cranial musculature of catfishes, with comments on plesiomorphic states. In Catfishes Edited by: Kapoor BG, Arratia G, Chardon M, Diogo R. Enfield: Science Publishers; 2003:47-69.

38. Stiassny MLJ: Gross functional anatomy: muscular system. In The handbook of experimental animals Edited by: Bullock G, Bunton TE. London: Academic Press; 2000:119-128.

39. Diogo R, Chardon M: Homologies between different adductor mandibulae sections of teleostean fishes, with a special regard to catfishes (Teleostei: Siluriformes). J Morphol 2000, 243:193-208.

40. Diogo R: Morphological evolution, aptations, homoplasies, constraints, and evolutionary trends: catfishes as a case study on general phylogeny and macroevolution Enfield: Science Publishers; 2004.

4I. Greenwood PH: Hyoid and ventral gill arch musculature in osteoglossomorph fishes. Bull Brit Mus Nat Hist (Zool.) 197I, 22: $1-55$

42. Greenwood PH: Notes on the anatomy and classification of elopomorph fishes. Bull Br Mus Nat Hist (Zool.) 1977, 32:65- 103.

43. Tchernavin VV: Six specimens of Lyomeri in the British museum (with noted on the skeleton of the Lyomeri). J Linn Soc Lond Zool 1947, 4I:287-350.

44. Tchernavin VV: Further notes on the structure of the bony fishes of the order Lyomeri (Eurypharynx). J Linn Soc Lond Zool 1947, 41:387-393.

45. Tchernavin $\mathrm{V}$ : The feeding mechanisms of a deep-sea fish, Chauliodus sloani Schneider. Brit Mus Nat Hist (Lond) 1953, 1953: I-I0I.

46. Kardong KV: Vertebrates: comparative anatomy, function, evolution 3rd edition. New York: McGraw-Hill; 2002.

47. Bischoff TLW: Description anatomique du Lepidosiren paradoxa. Ann Sci Nat, ser 2 1840, I4:I |6-I59. 
48. Owen R: Description of the Lepidosiren annectens. Trans Linn Soc Lond I84I, 18:327-36I.

49. Bemis WE: Feeding mechanisms of living Dipnoi: anatomy and function. J Morphol 1986:249-275.

50. Bemis WE, Lauder CV: Morphology and function of the feeding apparatus of the lungfish, Lepidosiren paradoxa (Dipnoi). J Morphol 1986, 187:8I-108.

51. Bartsch P: Development of the cranium of Neoceratodus forsteri, with a discussion of the suspensorium and the opercular apparatus in Dipnoi. Zoomorphol 1994, I | 4: I-3 I.

52. Lubosch W: Vergleischende anatomie der kaumusculatur der Wirbeltiere, in fünf teilen: I - die kausmukulatur der Amphibien. Jen Z Naturwiss 1914, 53:5 I-I88.

53. Jarvik $E$ : The composition of the intermandibular division of the head in fishes and tetrapods and the diphyletic origin of the tetrapod tongue. Kungl Sven Veten Handl 1963, 9:1-74.

54. Jarvik E: Basic structure and evolution of Vertebrates London: Academic Press; 1980

55. Larsen JH, Guthrie DJ: The feeding system of terrestrial tiger salamanders (Ambystoma tigrinum melanostictum Baird). J Morph 1975, 147:137-154.

56. Carroll RL, Holmes R: The skull and jaw musculature as guides to the ancestry of salamanders. Zool J Linn Soc 1980, 68: I-40.

57. Bauer WJ: A contribution to the morphology of the $\mathbf{m}$. interhyoideus posterior (VII) of urodele Amphibiia. Zool Jb Anat 1992, 122:129-139.

58. Haas A: The mandibular arch musculature of anuran tadpoles with comments on the homologies of amphibian jaw muscles. J Morphol 200I, 247: I-33.

59. Wiley EO: Ventral gill arch muscles and the interrelationships of gnathostomes, with a new classification of the Vertebrata. J Linn Soc (Zool) 1979, 67:149-179.

60. Wiley EO: Ventral gill arch muscles and the phylogenetic interrelationships of Latimeria. Occ Pap Calif Acad Sci 1979, 134:56-67.

61. Lauder GV, Liem KF: The evolution and interrelationships of the actinopterygian fishes. Bull Mus Comp Zool 1983, 150:95-197.

62. Brock GT: The cranial muscles of the Gecko - a general account with a comparison of muscles in other gnathostomes. Proc Zool Soc Lond ser B 1938, 108:735-761.

63. Gorniak GC: Trends in the action of mammalian masticatory muscles. Am Zool 1985, 25:331-337.

64. Pough FH, Heiser JB, McFarland WN: Vertebrate Life 4th edition. New Jersey: Prentice-Hall; 1996.

65. Kardong KV, Zalisko E): Comparative vertebrate anatomy - a laboratory dissection guide New York: McGraw-Hill; 1998.

66. Gibbs S, Collard M, Wood BA: Soft-tissue characters in higher primate phylogenetics. Proc Natl Acad Sci US 2000, 97: III30-11132

67. Gibbs S, Collard M, Wood BA: Soft-tissue anatomy of the extant hominoids: a review and phylogenetic analysis. J Anat 2002, 200:3-49.

68. Kisia SM, Onyango DW: Muscular system of vertebrates Enfield: Science Publishers; 2005

69. Lauder GV: Evolution of the feeding mechanisms in primitive actinopterygian fishes: a functional anatomical analysis of Polypterus, Lepisosteus, and Amia. J Morphol 1980, 163:283-317.

70. Higashijima S, Okamoto H, Ueno N, Hotta Y, Eguchi G: High-frequency generation of transgenic zebrafish which reliably express GFP in whole muscles or the whole body by using promoters of zebrafish origin. Dev Biol 1997, 192:289-299.

71. Westerfield M: The Zebrafish Book: A Guide for the Laboratory Use of Zebrafish Oregon: University of Oregon Press; 1995.

72. Carroll AM, Wainwright PC: Functional morphology of feeding in the sturgeon, Scaphirhyncus albus. J Morphol 2003, 256:270-284.

73. Jordansky NN: Jaw muscles of the Urodela and Anura: some features of development, functions, and homology. Zool Jb Anat 1992, 1 22:225-232

74. Abdala V, Moro S: A cladistic analysis of ten lizard families (Reptilia: Squamata) based on cranial musculature. Russ J Herpetol 2003, 10:53-78

75. Lauder GV: On the evolution of the jaw adductor musculature in primitive gnathostome fishes. Breviora 1980, 460:1-10.
76. Herrel A, Canbek M, Ozelmas U, Uyanoglu M, Karakaya M: Comparative functional analysis of the hyolingual anatomy in lacertid lizards. Anat $\operatorname{Rec} A$ 2005, 284:56I-573.

77. Lauder GV, Shaffer HB: Ontogeny of functional design in tiger salamanders (Ambystoma tigrinum): are motor patterns conserved during major morphological transformations? J Morphol 1988, 197:249-268.

78. Stiassny MLJ, Wiley EO, Johnson GD, De Carvalho MR: Gnathostome fishes. In Assembling the tree of life Edited by: Donaghue MJ, Cracraft J. New York: Oxford University Press; 2004:410-429.

79. Saban R: Musculature de la tête. In Traité de Zoologie Edited by: Grassé PP. Paris: Masson et Cie; 1968:229-47I.

80. Barghusen HR: The lower jaw of cynodonts (Retilia, Therapsida) and the evolutionary origin of mammal-like adductor jaw musculature. Postilla 1968, I I6: I-49.

81. Lightoller GS: Matrices of the facialis musculature - homologization of the musculature in monotremes with that of marsupials and placentals. J Anat 1942, 76:258-269.

82. Huber E: Evolution of Facial Musculature and Expression Baltimore: The Johns Hopkins University Press; 1931.

83. Greene EC: Anatomy of the Rat New York: Hafner Publishing Co.; 1935

Publish with Bio Med Central and every scientist can read your work free of charge

"BioMed Central will be the most significant development for disseminating the results of biomedical research in our lifetime. "

Sir Paul Nurse, Cancer Research UK

Your research papers will be:

- available free of charge to the entire biomedical community

- peer reviewed and published immediately upon acceptance

- cited in PubMed and archived on PubMed Central

- yours - you keep the copyright
BioMedcentral 